Cornell Law Library

Scholarship@Cornell Law: A Digital Repository

Cornell Law Faculty Publications

$1-1-2009$

\title{
Employment Discrimination Plaintiffs in Federal Court: From Bad to Worse?
}

\author{
Kevin M. Clermont \\ CornellLawSchool,kmc12@cornell.edu \\ Stewart J. Schwab \\ Cornell LawSchool, sjs15@cornell.edu
}

Follow this and additional works at: http://scholarship.law.cornell.edu/lsrp_papers
Part of the Civil Procedure Commons, Labor and Employment Law Commons, and the Litigation Commons

\section{Recommended Citation}

Clermont, Kevin M. and Schwab, Stewart J., "Employment Discrimination Plaintiffs in Federal Court: From Bad to Worse?" (2009). Cornell Law Faculty Publications. Paper 109.

http://scholarship.law.cornell.edu/lsrp_papers/109 


\title{
Employment Discrimination Plaintiffs in Federal Court: From Bad to Worse?
}

\author{
Kevin M. Clermont* \\ Stewart J. Schwab**
}

\section{INTRODUCTION}

Five years ago we surveyed how employment discrimination plaintiffs

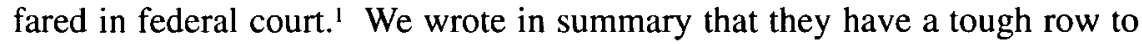
hoe. Compared to other plaintiffs, they manage fewer resolutions early in litigation, and so they have to proceed to trial more often. They win a lower proportion of cases during pretrial and at trial. Then, more of their successful cases undergo appeal. On appeal, they have a harder time both in preserving their successes and in reversing adverse outcomes.

This tough tale was an important story for several obvious reasons. For one, employment discrimination cases, the so-called "jobs" category, had come to constitute a very big fraction of the federal civil docket. Such cases then reigned as the largest single category of federal civil cases, at nearly ten percent of that docket.

In this Article, we update the tale, again by using governmental data but now using five more years of data. ${ }^{2}$ The new data show that things have indeed changed in employment discrimination litigation. ${ }^{3}$

* Flanagan Professor of Law, Cornell University.

** Allan R. Tessler Dean and Professor of Law, Cornell University. The authors would like to thank John Donohue, Peter Siegelman, and Nicole Waters for their comments.

' Kevin M. Clermont \& Stewart J. Schwab, How Employment Discrimination Plaintiffs Fare in Federal Court, 1 J. EmpiRICAL LeGAl. Stud. 429 (2004); see also Kevin M. Clermont et al., How Employment-Discrimination Plaintiffs Fare in the Federal Courts of Appeals, 7 EMP. RTs. \& EMP. PoL'Y J. 547 (2003).

2 All these data were gathered by the Administrative Office of the United States Courts ("AO"), assembled by the Federal Judicial Center, and disseminated by the Inter-university Consortium for Political and Social Research. See Theodore Eisenberg \& Kevin M. Clermont, Courts in Cyberspace, $46 \mathrm{~J}$. LegAl Educ. 94 (1996). These data convey details of all cases terminated in the federal courts since fiscal year 1970. When any civil case terminates in a federal district court or court of appeals the court clerk transmits to the AO information about the case, including the names of the parties, the subject matter category (chosen from about ninety categories, including specific branches of contract, tort, and other areas of law) and the jurisdictional basis of the case, the case's origin in the district as original or removed or transferred, the amount demanded, the dates of filing and termination in the district court or the court of appeals, the procedural stage of the case at termination, the procedural method of disposition, and, if the court entered judgment or reached a decision, the prevailing party and the relief granted. Thus, the computerized database, compiled from this information, contains all of the millions of federal civil cases over many years from the whole country. Kevin M. Clermont \& Theodore Eisenberg, Litigation Realities, 88 CoRnell L. Rev. 119, 127-29 (2002) [hereinafter Realities], more fully describes this database and its strengths and weaknesses.

${ }^{3}$ Or rather they keep changing. See John J. Donohue III \& Peter Siegelman, The Changing Nature of Employment Discrimination Litigation, 43 STAN. L. REv. 983 (1991) [hereinaf- 
Most notably, the category has seen a startling drop in the number of cases disposed of by the federal district courts-the category has dropped in absolute number of terminations every year after fiscal year 1999, and it has dropped as a percentage of the docket every year after fiscal year 2001.4 Now accounting for under six percent of the federal civil docket, it is no longer the top category, as it has fallen behind personal injury product liability cases and habeas corpus petitions.

This Article will tell a number of stories concerning the number of jobs cases and trials, the rate of success in the district courts, and the incidence and effects of appeal. This is an empirical piece in which the observed facts should speak for themselves in regard to appropriate reforms. Indeed, we wish to let each of these stories of litigating and deciding employment discrimination actions unfold mainly through our displays, in the form of straightforward graphs and tables. ${ }^{5}$

Nevertheless, we should disclose at the outset our concluding view that results in the federal courts disfavor employment discrimination plaintiffs, who are now forswearing use of those courts. Our study of the federal district courts shows employment discrimination plaintiffs bring many fewer cases now. Jobs cases proceed and terminate less favorably for plaintiffs than other kinds of cases. Plaintiffs who appeal their losses or face appeal of their victories again fare remarkably poorly in the circuit courts. The fear of judicial bias at both the lower and the appellate court levels may be discour-

ter Changing Nature]; John J. Donohue III \& Peter Siegelman, The Evolution of Employment Discrimination Law in the 1990s: A Preliminary Empirical Investigation, in HANDBOOK OF Employment Discrimination Research: Rights and Realities 261 (Laura Beth Nielsen \& Robert L. Nelson eds., 2005) [hereinafter Evolution].

4 We focus on code \#442, "Civil Rights: Jobs" or "Employment," which includes mainly Title VII actions, but also 42 U.S.C. $\$ \S 12101-12213$ (Americans with Disabilities Act (“ADA")), 42 U.S.C. § 1983 (civil rights), 29 U.S.C. $\$ \$ 621-34$ (Age Discrimination in Employment Act ("ADEA")), 42 U.S.C. $\$ 1981$ (equal rights), and 29 U.S.C. \$§ 2601-54 (Family and Medical Leave Act ("FMLA")) actions. Code \#442 includes actions under 42 U.S.C. $\S 1981$ or $\S 1983$ or under the ADA only if they were employment related; many actions under these statutes fall into code \#440, "Other Civil Rights." The coding is not perfect; for example, some FMLA cases end up in other codes, such as code \#790, "Other Labor Litigation," or code \#890, "Other Statutory Actions," and so escape our count. Moreover, in fiscal year 2005 , the AO peeled ADA cases off into new codes \#445, ADA-Employment, and \#446, ADA-Other; in calendar year 2005, these two codes comprised 182 and 511 cases, respectively, and in calendar year 2004, one and zero cases, respectively.

Only around fiscal year 1970, following the tremendous increase in civil rights actions in the 1960s, see 1971 Annual Report of THE Director of THE Administrative OfFice of THE U.S. COURTS 120 , did the AO create a separate category for civil rights actions concerning employment, namely, code \#442. Because of the unavoidable delay in full utilization of the new code in termination data, and because of later critical improvements in the AO's coding (for example, only since fiscal year 1979 do the data indicate which party prevailed by judgment in the district court), we shall give most of our results from 1979 onward. We now have computerized data through fiscal year 2006, the most recently released year. Because it is clearer to speak in terms of calendar years rather than fiscal years, we shall give results henceforth in terms of calendar years.

"On the use of the term "display," see Nicholas J. Cox, Speaking Stata: Problems with Tables, Part I, 3 Stata J. 309, 309 (2003) ("In a wider context, ... tables and graphs are all reasonably considered as exhibits or displays of some kind."). 
aging potential employment discrimination plaintiffs from seeking relief in the federal courts.

In Part I we begin our stories with appellate courts. In Part II we turn to the lower courts. ${ }^{6}$ The reason for that order is that the anti-plaintiff story in the federal courts of appeals may help us to understand the recent doings in the district courts, including the sharp drop in caseload.

\section{Courts of Appeals}

\section{A. Affirmance Effect}

While win rates in the trial court vary from high to low across case categories, affirmance rates in the appellate court are elevated for all kinds of cases. ${ }^{7}$ Display 1 shows this pattern. It separates into jobs cases and all other civil cases the federal court data on judgments for plaintiff or defendant and decisions for appellant or appellee. The lower two lines comprise the plaintiff win rates at district court trials for the two sets of cases, each line limited to trial results so that the win rate can be most meaningful. ${ }^{8}$ Although we shall dissect the pattern later, ${ }^{9}$ note for now that the win rate over time is fairly steady or perhaps descending for non-jobs cases, while jobs cases have a much lower win rate but one that had been gently increasing over most of the period. The two lines near the top comprise affirmance rates for jobs cases and all other civil cases, each line combining appeals from trials and other dispositions and by plaintiffs and defendants into a

${ }^{6}$ For a sketch of the still-lower levels of the employment discrimination dispute pyramid, those that precede a court filing, see Richard E. Miller \& Austin Sarat, Grievances, Claims, and Disputes: Assessing the Adversary Culture, 15 Law \& Soc'y Rev. 525, 544 (1981); Laura Beth Nielsen \& Robert L. Nelson, Rights Realized? An Empirical Analysis of Employment Discrimination Litigation as a Claiming System, 2005 WIS. L. Rev. 663, $703-07$ (2005).

${ }^{7}$ The "win rate" is the fraction of plaintiff wins among judgments for either plaintiff or defendant, not for both or for an unknown party. Note that these judgments can comprise much more than trial outcomes. For AO purposes, judgments might be the result of adjudication, consent, or default, but they normally do not include voluntary dismissals or dismissals for lack of prosecution.

The "affirmance rate," which is the complement of the reversal rate, means the percentage of appeals that reach a decisive outcome and are affirmed rather than reversed. We narrowly define "affirmed" as affirmed or dismissed on the merits. We define "reversed" as reversed, remanded, or modified, in part or completely.

8 "Trial" combines jury and judge trials. We used the procedural progress codes of 7 and 9-termination during and after jury trial-to define jury trial usage. However, we abandoned the procedural progress codes for judge trials because, unfortunately, the AO defines "trial" to include all contested proceedings in which evidence is introduced. See Administrative OF. fice of the U.S. Courts, Civil Statistical Reporting Guide 3:18 (1999). This definition would distort analysis of the data by categorizing some motion hearings as judge trials. See Patrick E. Higginbotham, So Why Do We Call Them Trial Courts?, 55 SMU L. Rev. 1405, 1405-06 (2002). Instead, we used the disposition method code of 9-judgment on court trial-to define judge trial usage. We used these mixed definitions for trials throughout the article, except in Displays 8 and 9 and footnote 57, where we broke down the cases uniformly by method of disposition or by procedural progress.

${ }^{9}$ See infra Part II.C. 
single rate. The affirmance rate for jobs is slightly higher than that for nonjobs in the last decade. In short, jobs cases are usually unsuccessful below, and the district court results usually meet affirmance on appeal.

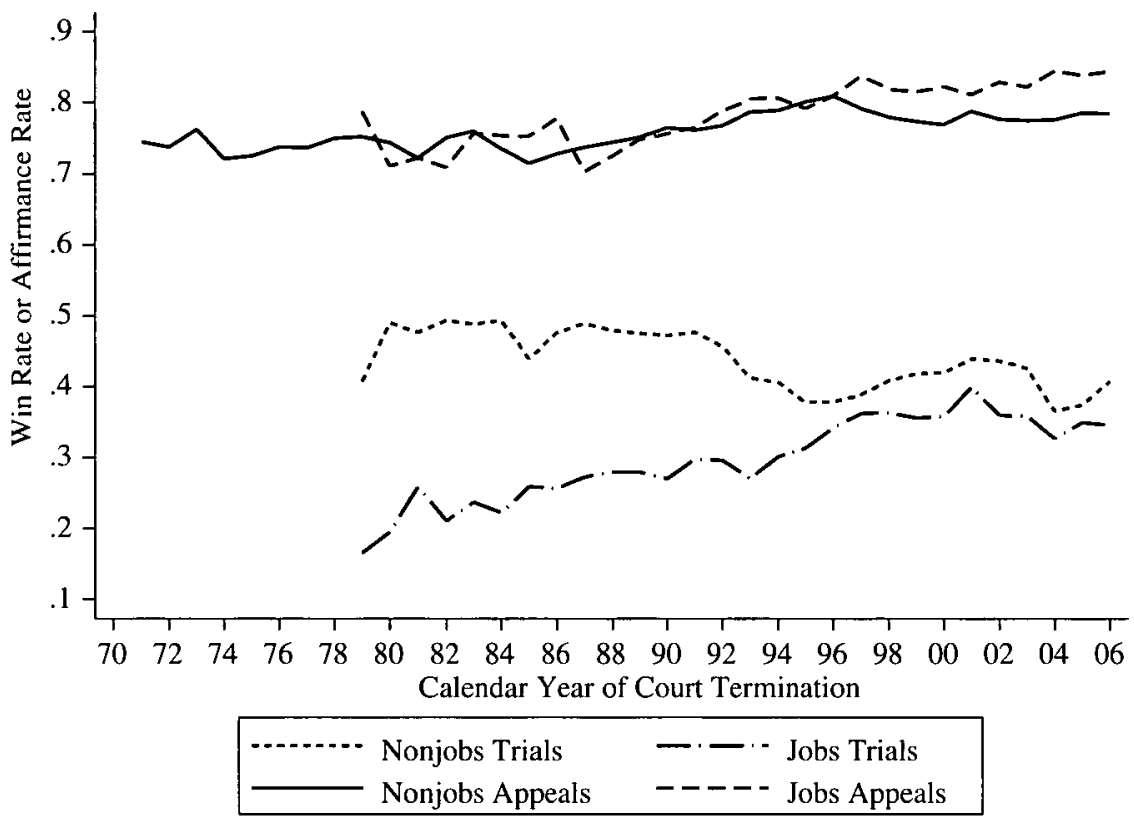

Display 1: Plaintiff Win Rates at Trial in Employment Discrimination and Other Civil Cases, 1979-2006, U.S. District Courts; Affirmance Rates on All Appeals in Employment Discrimination and Other Civil Cases, 1970-2006, U.S. Courts of Appeals. This graph of AO data shows the closing gap in win rates for trials (the bottom two lines), and the comparability of affirmance rates (the top two lines), for employment discrimination and other cases.

The most striking feature of appeals is the high rate of affirmance. ${ }^{10}$ Our work in a number of articles shows the affirmance rate for federal civil appeals to be about eighty percent." At first glance, this affirmance effect seems unsurprising. One might expect a high affirmance rate because of frequent appellate deference to the district court's result. ${ }^{12}$ One might even expect a high affirmance rate when review is de novo, because of the ten-

${ }^{10}$ This high number is characteristic of appellate courts with a predominantly mandatory docket, such as the federal courts of appeals. See Theodore Eisenberg \& Geoffrey P. Miller, Reversal, Dissent, and Variability in State Supreme Courts: The Centrality of Jurisdictional Source 2, 8, 15-23, 37-38 (NYU Sch. of Law, Public Law \& Legal Theory, Research Paper No. 08-01, Jan. 2008) available at http://ssrn.com/abstract $=1080563$ (finding a forty-eight percent affirmance rate for state appellate courts with discretionary jurisdiction and attributing this to the selection effect of justices picking which cases to hear).

${ }^{11}$ E.g., Kevin M. Clermont \& Theodore Eisenberg, Appeal from Jury or Judge Trial: Defendants' Advantage, 3 AM. L. \& ECon. Rev. 125, 130-34 (2001) [hereinafter Defendants' Advantage]; Kevin M. Clermont \& Theodore Eisenberg, Plaintiphobia in the Appellate Courts: Civil Rights Really Do Differ from Negotiable Instruments, 2002 U. ILL. L. REv. 947, 968-71 [hereinafter Plaintiphobia].

${ }^{12}$ See Kevin M. Clermont, Procedure's Magical Number Three: Psychological Bases for Standards of Decision, 72 Cornell L. Rev. 1115, 1126-31 (1987). 
dency of experts to agree on matters within the fields of their expertise at about a seventy-five percent rate. ${ }^{13}$ These two factors together might push the expected rate of affirmance close to eighty percent. ${ }^{14}$

However, if the high affirmance rate is owing to these two factors, why do the parties not take them into account and settle all but the close appeals, thereby whittling down that high affirmance rate? The usual brand of caseselection theory says that appeals should act like trials. ${ }^{15}$ Indeed, simplistic case-selection theorizing would predict a fifty percent affirmance rate. The data clearly reject that prediction.

Thus, the persistently elevated affirmance rate suggests that settlement is not very effective during the appellate phase in weeding out clear cases. After all, if every judgment underwent appeal, one would expect about an eighty percent affirmance rate because of reviewer's deference and experts' agreement. In fact, only a fraction of judgments undergo appeal-less than a fifth of decisive judgments, with less than half of these proceeding all the way to a decisive appellate outcome ${ }^{16}$-yet one sees an eighty percent affirm-

${ }^{13}$ See Kevin M. Clermont \& Theodore Eisenberg, Trial by Jury or Judge: Transcending Empiricism, 77 CoRnell L. Rev. 1124, 1153-54 (1992) [hereinafter Trial by Jury].

${ }^{14}$ See also Chris Guthrie \& Tracey E. George, The Futility of Appeal: Disciplinary Insights into the "Affirmance Effect" on the United States Courts of Appeals, 32 FLA. ST. U. L. REv. 357 (2005) (adding political-science and psychology explanations of the tendency to affirm); $c f$. Harlon Leigh Dalton, Taking the Right to Appeal (More or Less) Seriously, 95 YALE L.J. 62 (1985) (questioning the worth of appellate courts as an error-correction device).

${ }^{15}$ See Defendants' Advantage, supra note 11, at $132 \mathrm{nn} .11-12$. Case selection theory accounts for the fact that win-rate or affirmance-rate data convey the system's output while hiding the variable composition of its input.

More specifically, disputes and cases that clearly favor either the plaintiff or the defendant tend to settle readily, because both sides can save costs by settling in light of their knowledge of the applicable law and all other aspects of the case. Difficult cases falling close to the applicable decisional criterion tend not to settle, because the parties are more likely to disagree substantially in their predicted outcomes. These unsettled close cases fall more or less equally on either side of the criterion, regardless of that criterion's position and regardless of the underlying distribution of disputes or cases. Thus, case selection will leave for adjudication a residue of unsettled close cases, which consequently exhibit some nonextreme equilibrium success rate.

The parties' selection of which cases to push into and through litigation produces a biased sample from the mass of underlying disputes. This means that the actual success rate reveals something about the set of adjudged cases, a universe dominated by close cases-but reveals not much about the underlying, variegated mass of disputes and cases, and little about its treatment in the litigation process. According to case-selection effect theory, any distinction between two streams of cases that the parties evaluate without systematic inaccuracy should lead to no difference in adjudicated success rates. Indeed, under simplifying assumptions, and as a limiting implication, the theory suggests a success rate of fifty percent for both streams.

Actually, however, the fully developed theory does not predict any universal success rate, nor even that any two streams' rates will be the same. Reality is too complicated to produce a fifty percent rate. There are three main types of factors that might lead to win rates different from fifty percent: differential stakes; parties' misperceptions; and influences such as case strength that survive because of imperfect case selection. That last set of influences does mean that success rates may retain residual meaning, which the settlement process has not obliterated. Careful research and theorizing can often succeed in untangling the neutralizing effect of settlement. The challenge is to tease out the residual meaning in success-rate data.

${ }^{16}$ See id. at $130-31,154$ (showing a rate of appeal just over $20 \%$ for a selection of decisive judgments rendered upon pretrial motion or trial, and indicating that $11.3 \%$ went all the 
ance rate. It seems as if the parties have chosen to appeal, by whatever selection method they employ, a set of cases that is not random but functions, at least with regard to overall affirmance, as if it were a random sampling. That is, case selection might have a very limited effect in systematically filtering the cases for adjudication on appeal. ${ }^{17}$

Why would that be? Judgment below leaves the winner feeling vindicated, and the aggrieved loser still wanting justice. Something telling emerges in the countless scenes on the evening news in which losers proclaim on the courthouse steps their intention to appeal. After slogging through the district court, the losing party must see the additional cost and effort of appeal as insignificant when compared to the big return of reversal. Nearly a fifth of losing parties decide that they might as well stagger to the finish line, seemingly regardless of their chances on appeal. Perhaps, then, the failure to filter out clear-cut appeals is owing to appeals not being very costly in relative terms.

\section{B. Anti-Plaintiff Effect}

Appeal rates, we thus posit, turn mainly on the cost of appeal. Affirmance rates reflect mainly the absence of selection effects. Therefore, these gross rates may not have much to tell about the quality of justice. It may be that the only real story to tell about employment discrimination litigation arises in the district courts. But before so concluding, one should dive more deeply into the appellate results. ${ }^{18}$

way to affirmance or reversal); Plaintiphobia, supra note 11, at 951-52, 967 (showing a rate of appeal around $15 \%$ for all judgments, and indicating $7.4 \%$ go to affirmance or reversal). Both studies used data from fiscal years 1988-1997.

${ }^{17}$ Other evidence seems to confirm case selection's limited effect on appeal. See, e.g., Eisenberg \& Miller, supra note 10 . Most notably, a rich literature shows that appellate judges' attitudes (or ideologies) and other factors including case strength influence success rates. See Jeff Yates \& Elizabeth Coggins, The Intersection of Judicial Attitudes and Litigant Selection Theories: Explaining U.S. Supreme Court Decision Making 7-13, 19-21, 30-31 (2008) (unpublished manuscript, on file with authors). The role of attitudes would be hidden if case selection were robust on appeal.

The state data from the National Center for State Courts, http://www.icpsr.umich.edu/cocoon/NACJD/STUDY/04539.xml, indicate that affirmance rates are considerably higher when a deferential standard of review governs than when a nondeferential standard governs. See also Frank B. Cross, Decision Making in the U.S. Courts of Appeals 49-53 (2007) (indirectly showing a similar result for the federal courts of appeals, while generally finding that case strength and judicial attitudes influence affirmance rates for those courts). If case selection were operating, the affirmance rates under different standards of review should tend to equate.

Some evidence goes the other way, however. See Daniel Kessler et al., Explaining Deviations from the Fifty-Percent Rule: A Multimodal Approach to the Selection of Cases for Litigation, 25 J. Legal STUD. 233, 254, 256-57 (1996) (finding some selection effects on appeal).

${ }^{18} \mathrm{Up}$ to this point, we have used only the appellate court's data. But those data do not tell whether the appellant was plaintiff or defendant below. We can get at such revealing information only by combining the appellate data with the lower court data. By linking docket numbers in the AO's civil data from the federal district courts and its data from the federal courts of appeals, we can trace developments in cases after district court judgments appear on the appellate court's docket. See Plaintiphobia, supra note 11, at 950-51; Theodore Eisenberg, Appeal 
By far, most appeals in federal employment discrimination cases are appeals by plaintiffs, whether from trial or pretrial adjudications, ${ }^{19}$ as shown in Display 2's presentation of appeal rates. ${ }^{20}$ This fact mainly reflects that plaintiffs suffer most of the losses at the district court level. Although defendants' appeal rate is comparable to plaintiffs' appeal rate, plaintiffs' appeals $(12,608)$ are ten times more frequent in absolute numbers than defendants' appeals (1260).

Rates and Outcomes in Tried and Nontried Cases: Further Exploration of Anti-Plaintiff Appellate Outcomes, 1 J. Empirical LeGal Stud. 659, 661-63 (2004).

Both of these prior studies used data from fiscal years 1988-1997. For this article, we extended our previous data set to earlier years and also through fiscal year 2006 (the last year for which these data are currently available). However, we present results only for district court terminations beginning with calendar year 1988 (the first full year linkage became possible, as the AO started including all the docket numbers in its appellate data only in fiscal year 1988). Moreover, because some of the district court judgments late in our sample period did not have sufficient time to mature into appellate outcomes included in the sample, we present results only for district court terminations through calendar year 2004 to mitigate this data censoring problem.

If the judgment below was for plaintiff, we initially inferred that the defendant was the appellant. However, examining the parties' names revealed that more than a quarter of the appeals from judgment for plaintiff have a plaintiff as the named appellant. In earlier works, we simply discarded appeals from judgment for plaintiff in which an apparently dissatisfied but winning plaintiff was the named appellant or the defendant was the named appellee. See, e.g., Plaintiphobia, supra note 11 , at $951 \&$ n.12. Subsequent investigation, however, leads us to think that many of these appeals are defendant appeals in which the clerk mistakenly listed as appellant the first-named party in the appellate case's caption (always the plaintiff under current rules). One strong piece of evidence is that these appeals are geographically concentrated, coming by far most frequently from the Fifth Circuit. Moreover, the reversal rate for this special category of appeals is virtually identical to the defendants' reversal rate. See Eisenberg, supra, at 662 n.6, 683-84. We now retain these appeals as mislabeled defendant appeals, thus changing the observed appeal rates from the rates reported in our earlier works.

19 "Pretrial adjudication" comprises those cases whose method of disposition was coded as 6 , which means disposition by pretrial motion.

${ }^{20}$ We henceforth define the "appeal rate" as the percentage of those cases terminated in the district court by pretrial adjudication or at trial and with a judgment expressly for plaintiff or defendant, in which the appellate court issues a decisive outcome on the merits. We do not count as appeals the cases in which an appeal is docketed but no decisive outcome is reached on appeal, which often results from the case settling. A substantial number of appeals terminate without decisive outcomes. These dropped appeals are heavily appeals by defendants, who drop more appeals than do plaintiffs. Although defendants initiate appeal more often than plaintiffs (in our sample defendants initiated appeal from $45.31 \%$ of their trial losses, while plaintiffs pursued $33.01 \%$ of theirs), proportionately fewer of their appeals result in decisive outcomes (in our sample defendants carried appeals to decisive outcomes from $24.95 \%$ of their trial losses and plaintiffs from $22.08 \%$ of theirs). See Plaintiphobia, supra note 11, at 951-52; Eisenberg, supra note 18 , at $663-65$. 


\begin{tabular}{|c|c|c|c|c|}
\hline & \multicolumn{2}{|c|}{ Appeal Rates } & \multicolumn{2}{|c|}{ Reversal Rates } \\
\hline $\begin{array}{l}\text { Adjudication } \\
\text { Stage }\end{array}$ & $\begin{array}{l}\text { Percent of Cases } \\
\text { Appealed to } \\
\text { Conclusion After } \\
\text { Plaintiffs' Wins } \\
\text { (\#appeals/\#wins) }\end{array}$ & $\begin{array}{l}\text { Percent of Cases } \\
\text { Appealed to } \\
\text { Conclusion After } \\
\text { Defendants' Wins } \\
\text { (\#appeals/\#wins) }\end{array}$ & $\begin{array}{l}\text { Percent of } \\
\text { Appeals Reversed } \\
\text { After Plaintiffs' } \\
\text { Wins (\#reversals' } \\
\text { \#appeals) }\end{array}$ & $\begin{array}{l}\text { Percent of } \\
\text { Appeals Reversed } \\
\text { After Defendants' } \\
\text { Wins (\#reversals' } \\
\text { \#appeals) }\end{array}$ \\
\hline Pretrial & $\begin{array}{l}13.95 \\
(172 / 1233)\end{array}$ & $\begin{array}{l}24.00 \\
(10,598 / 44,157)\end{array}$ & $\begin{array}{l}30.23 \\
(52 / 172)\end{array}$ & $\begin{array}{l}10.69 \\
(1133 / 10,598)\end{array}$ \\
\hline Trial & $\begin{array}{l}24.95 \\
(1090 / 4368)\end{array}$ & $\begin{array}{l}22.08 \\
(2042 / 9248)\end{array}$ & $\begin{array}{l}41.10 \\
(448 / 1090)\end{array}$ & $\begin{array}{l}8.72 \\
(178 / 2042)\end{array}$ \\
\hline
\end{tabular}

Display 2: Appeal and Reversal Rates (and Numbers) in Employment Discrimination Cases by Decisional Stage, 1988-2004, U.S. Courts of Appeals. The second column of this table of $\mathrm{AO}$ data shows defendants' decisive appeals from decisive adjudications below, with defendants being less likely than plaintiffs to appeal their losses by pretrial adjudication, but more likely to appeal their losses at trial. The third column shows the plaintiffs' appeals, with plaintiffs appealing in much greater absolute numbers than defendants. The fourth column shows the defendants' outcomes, with defendants doing very well in obtaining reversals. The fifth column shows the plaintiffs' outcomes, with plaintiffs doing quite badly on appeal.

Display 3 shows that both defendants' and plaintiffs' appeal rates have been higher in employment discrimination cases than in other cases. That is, the employment discrimination category is a heavily litigated set of cases on appeal. However, the appeal rates have become less distinctive in the last five years. Incidentally, in those recent years it could be that the increasing

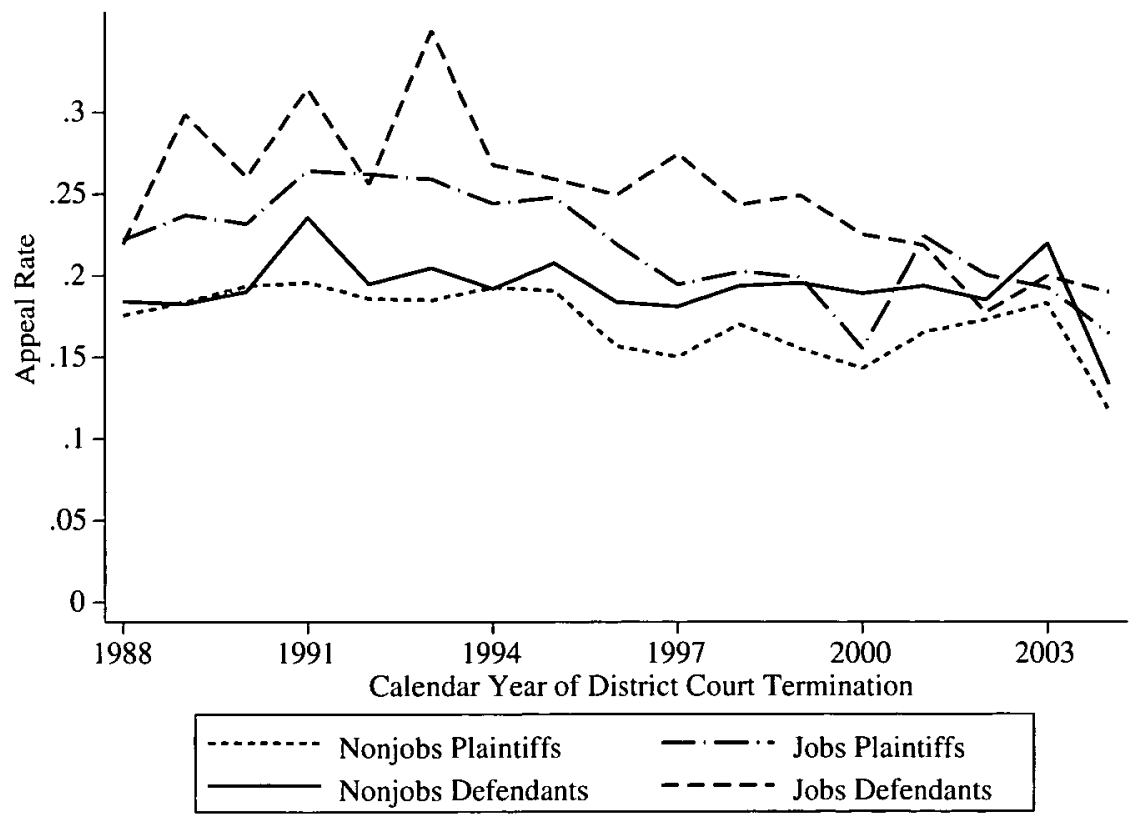

Display 3: Appeal Rates from Trial Losses for Plaintiffs and Defendants in Employment Discrimination and Other Civil Cases, 1988-2004, U.S. Courts of Appeals. This graph of AO data compares appeal rates from trials. Employment discrimination litigants (the top two lines) appeal more frequently than other litigants (the bottom two lines). In each of these two case types, defendants appeal more frequently than plaintiffs. 
percentage of jobs appeals being plaintiffs' appeals (ninety-five percent in 2004), combined with the fact that plaintiffs' appeals especially often result in affirmance, explains the recent ascendancy of the jobs affirmance rate shown in Display 1.

A starker fact is that the defendants' reversal rate far exceeds the plaintiffs' reversal rate, as also shown in Display 2. That is, the appellate courts reverse plaintiffs' wins below far more often than defendants' wins below. The statistically significant differential exists for appeals from wins at the stage of pretrial adjudication (thirty percent compared to eleven percent), and it becomes more pronounced for appeals from wins at the trial stage (forty-one percent compared to nine percent). ${ }^{21}$

Display 4 shows this advantage that defendants continue to enjoy on appeal. This effect appears in almost all case categories in Display 4, which shows thirty-five percent as the defendants' reversal rate from trial losses in non-jobs cases and fifteen percent as the plaintiffs' reversal rate. But the forty-one percent to nine percent spread between defendants' and plaintiffs'

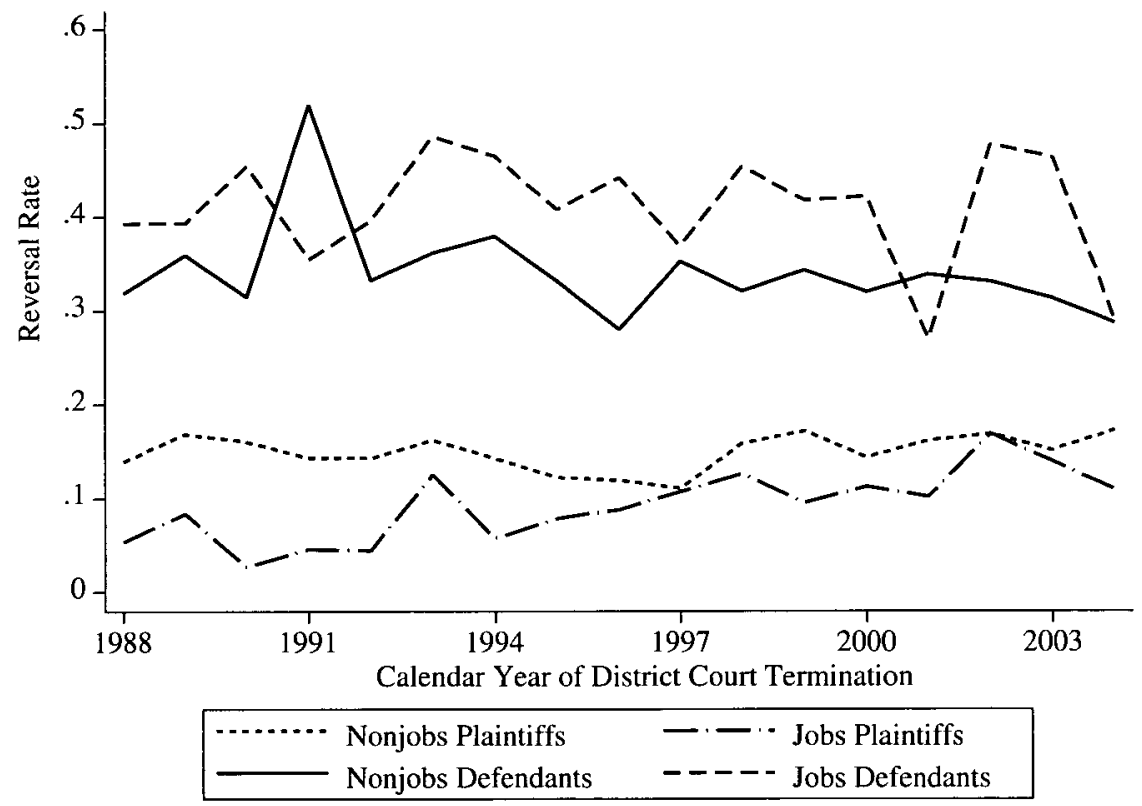

Display 4: Reversal Rates on Appeals from Trial Losses by Plaintiffs and Defendants in Employment Discrimination and Other Civil Cases, 1988-2004, U.S. Courts of Appeals. This graph of AO data compares reversal rates from trials. Defendants (the top two lines) enjoy more reversals than plaintiffs (the bottom two lines). The defendant/plaintiff difference in reversal rates is more extreme in employment discrimination cases (the top and bottom line) than in other cases.

${ }^{21}$ Even though we have altered our methodology somewhat, and lengthened the period under study, the reversal rates remain similar to our earlier results. See Clermont \& Schwab, supra note 1 , at 450 (differential of $42 \%$ compared to $8 \%$ for trials). Incidentally, the reversal rates for non-jobs cases, corresponding to those for jobs cases in Display 2, are $31.00 \%$ and $14.16 \%$ for pretrial and $35.12 \%$ and $14.74 \%$ for trial. 
reversal rates in jobs cases is more extreme than the spread in non-jobs cases, with jobs defendants doing better and jobs plaintiffs doing worse than their non-jobs counterparts. ${ }^{22}$

For a plaintiff victorious at trial in an employment discrimination case, the appellate process offers a chance of retaining victory that cannot meaningfully be distinguished from a coin flip. ${ }^{23}$ Meanwhile, a defendant victorious at trial can be assured of retaining that victory after appeal. Defendants, in sharp contrast to plaintiffs, emerge from appellate court in a much better position than they were in when they left trial court. In this surprising plaintiff/defendant difference in the federal courts of appeals, we have unearthed an anti-plaintiff effect that is troublesome.

The vulnerability on appeal of jobs plaintiffs' relatively few trial victories is more startling in light of the nature of these cases and the applicable standard of review. The bulk of employment discrimination cases turn on intent, and not on disparate impact. ${ }^{24}$ The subtle question of the defendant's intent is likely to be the key issue in a nonfrivolous employment discrimination case that reaches trial, putting the credibility of witnesses into play. When the plaintiff has convinced the fact finder of the defendant's wrongful intent, that finding should be largely immune from appellate reversal, just as defendants' trial victories are. Reversal of plaintiffs' trial victories in employment discrimination cases should be unusually uncommon. Yet we find the opposite.

Why would this plaintiff/defendant difference exist? This question requires some speculation. We have argued elsewhere that an attitudinal explanation of the anti-plaintiff effect is most persuasive. ${ }^{25}$ Both our

${ }^{22}$ See Plaintiphobia, supra note 11, at 957-59 (treating all civil cases); see also Kevin M. Clermont \& Theodore Eisenberg, Judge Harry Edwards: A Case in Point!, 80 WASH. U. L.Q. 1275, 1281-84 (2002) [hereinafter Judge Harry Edwards] (defending our results); Clermont et al., supra note 1 (treating employment discrimination appeals); Ruth Colker, Winning and Losing Under the Americans with Disabilities Act, 62 Oнı ST. L.J. 239 (2001) (confirming the defendants' advantage on appeal, which the author had earlier reported from bare outcome data, by an in-depth consideration of ADA employment discrimination opinions on Westlaw); Lynne Liberato \& Kent Rutter, Reasons for Reversal in the Texas Courts of Appeal, 44 S. Tex. L. Rev. 431, 458 (2003) (showing results similar to ours, in a comprehensive study of a year's appellate decisions in one state's courts, including a defendant/plaintiff differential in reversal rates for employment cases of $52 \% / 20 \%$ ). As to this anti-plaintiff effect, the state data tell a similar story. See Theodore Eisenberg \& Michael Heise, Plaintiphobia in State Court? An Empirical Study of State Court Trials on Appeal, 38 J. LEGAL STuD. (forthcoming Jan. 2009), available at $\mathrm{http}: / / \mathrm{ssrn} . \mathrm{com} / \mathrm{abstract}=988199$.

${ }^{23}$ See Plaintiphobia, supra note 11, at 957-58.

${ }^{24}$ See Changing Nature, supra note 3 , at 989,998 \& n.57.

${ }^{25}$ See generally Kevin M. Clermont \& Theodore Eisenberg, Anti-Plaintiff Bias in the Federal Appellate Courts, 84 JudiCATURE 128 (2000); Defendants' Advantage, supra note 11; Judge Harry Edwards, supra note 22; Realities, supra note 2, at 150-54; Plaintiphobia, supra note 11; Clermont et al., supra note 1. Appellate/trial differences in attitude surely have an effect in certain types of cases. See, e.g., Timothy Davis Fox, Right Back "In Facie Curiae"A Statistical Analysis of Appellate Affirmance Rates in Court-initiated Attorney-Contempt Proceedings, 38 U. MEM. L. REv. 1, 2 (2007) ("The affirmance rate for the general appellate case population is in excess of $70 \%$. The affirmance rate of the 932 court-initiated attorney-contempt [findings in Westlaw] cases included in this study is only about $32 \%$."). 
descriptive analyses of the results and our more formal regression models tended to dispel explanations based solely on selection of cases, and instead to support an explanation based on appellate judges' attitudes toward triallevel adjudicators.

Appellate judges may perceive trial courts as pro-plaintiff. An appellate court consequently would be more favorably disposed to a defendant than would be a trial judge or jury. This appellate favoritism would be appropriate if the trial courts were in fact biased in favor of plaintiffs. Yet employment discrimination cases constitute one of the least successful categories at the district court level, in that plaintiffs win a very small percentage of their actions and fare worse than in almost any other category of civil case. ${ }^{26}$ If district courts were biased in favor of employment discrimination plaintiffs and still produced such a low plaintiff win rate, they would have to be starting with a class of cases truly abysmal in strength. More likely, district courts process employment discrimination cases with a neutral or even jaundiced eye toward plaintiffs. ${ }^{27}$ As empirical evidence accumulates to refute trial court bias in favor of plaintiffs, ${ }^{28}$ any perceptions held by appellate judges that such a bias exists appear increasingly to be misperceptions.

Alternatively, unconscious biases may be at work at the appellate level. Perhaps appellate judges' distance from the trial process creates an environment in which it is easy to discount harms to the plaintiff. ${ }^{29}$ The biases do not have to be peculiar to appellate judges, however. Litigation-reform propaganda may have made us all a bit anti-plaintiff. ${ }^{30}$ No matter the source, because the appellate court acts after the trial court's biases have played out, any appellate biases would produce an anti-plaintiff effect on appeal. Recall that the selection effect is quite limited at the appellate stage.

If jobs plaintiffs' disadvantage on appeal does rest on appellate courts' biases or misperceptions that trial courts are pro-plaintiff, one might expect a similar disadvantage to be evident in cases systematically involving under-

${ }^{26}$ See Trial by Jury, supra note 13, at 1175.

${ }^{27}$ See Valerie P. Hans, Business on Trial, 36 (2000) ("The broad message is that jurors often doubt plaintiffs' claims and report the need to balance their sympathies with a detailed assessment of the plaintiff's role in the injury."); Valerie P. Hans \& Stephanie Albertson, Empirical Research and Civil Jury Reform, 78 Notre Dame L. Rev. 1497, $1506-09$ (2003) (discussing evidence of anti-plaintiff sentiment among jurors); Valerie P. Hans \& Nicole Vadino, Whipped by Whiplash? The Challenges of Jury Communication in Lawsuits Involving Connective Tissue Injury, 67 TENN. L. REv. 569, 572-73 (2000) (discussing evidence of anti-plaintiff sentiment among the public). In particular, the trial judge may be more jaundiced toward employment discrimination plaintiffs than the jury is. See infra text accompanying note 70 .

${ }_{28}$ See Realities, supra note 2, at 144-47.

${ }^{29}$ See Stanton Wheeler et al., Do the "Haves" Come Out Ahead? Winning and Losing in State Supreme Courts, 1870-1970, 21 L. \& Soc'y REv. 403, 408-09 (1987). For anecdotal support, and fictional at that, see JoHn Grisham, The Appeal 335-36 (2008):

Justice Calligan had never managed to see liability in any death or injury case. He believed jurors were stupid and easily led astray by slick trial lawyers. And he believed that it was his solemn responsibility to correct every miscarriage of justice (plaintiff's verdict) from the comfort of his detached environment.

${ }^{30}$ See Marc Galanter, An Oil Strike in Hell: Contemporary Legends About the Civil Justice System, 40 ARIz. L. Rev. 717 (1998). 
dogs as plaintiffs. The disadvantage is in fact strongest for other civil-rightstype cases, ${ }^{31}$ which share a near-systematic feature of underdog plaintiffs, ${ }^{32}$ and which moreover include many discrimination, police misconduct, and First Amendment issues that may ultimately depend on the motives of official decisionmakers. ${ }^{33}$ The very high plaintiff/defendant differential in reversal rates for other civil-rights-type cases reinforces the likelihood that antiplaintiff appellate attitudes explain the similar differential in jobs cases. But whatever the precise nature of the appellate attitudes, any appellate leaning in favor of defendants should be cause for concern. ${ }^{34}$

${ }^{31}$ See Clermont et al., supra note 1, at 559.

${ }^{32}$ See, e.g., Jon O. Newman, Suing the Lawbreakers: Proposals to Strengthen the Section 1983 Damage Remedy for Law Enforcers' Misconduct, 87 YALE L.J. 447, 454 (1978) (federal judge noting: "Except in those rare instances when the party injured is the white, middle-class victim of police mistake, the section 1983 plaintiff is likely to be black or Puerto Rican, poor, disheveled, a felon, and often a drug addict.").

${ }^{33}$ See Theodore Eisenberg \& Sheri Lynn Johnson, The Effects of Intent: Do We Know How Legal Standards Work?, 76 Cornelt L. Rev. 1151, 1164-65 (1991); Stewart J. Schwab \& Theodore Eisenberg, Explaining Constitutional Tort Litigation: The Influence of the Attorney Fees Statute and the Government as Defendant, 73 Cornell L. Rev. 719, 735 (1988).

${ }^{34}$ What is the best counterargument to our attitudinal explanation of the anti-plaintiff effect revealed by the data? It is that these kinds of plaintiffs start with very weak cases, present them less effectively than the defendants, and then appeal their losses too frequently. See Eisenberg, supra note 18, at 677-82 (strengthening the counterargument by making strong assumptions for the purpose of argument, including an unrealistic selection effect on appeal).

How could we respond? It merits stressing that we have never claimed that our attitudinal explanation of the anti-plaintiff effect is irrefutable. We are looking at output data, after all: by making appropriate assumptions about the input, one can explain any particular pattern in the output data. It is true that weak cases, ineffectively pushed by plaintiffs who also appeal too readily, will mathematically result in a higher reversal rate for defendants, and so could produce the look of an anti-plaintiff effect in reversal rates by perfectly neutral courts. So, although we concede that this counterargument is coherent, we maintain that it is unconvincing in this setting for a number of reasons.

First, as we have repeatedly said, there is no empirical basis for inferring such a difference between the strength of plaintiffs' and defendants' cases, nor in the effectiveness of their presentation, even though one might initially imagine these employment discrimination plaintiffs as prone to fight the valiant-though-losing battle as a form of protest. Jobs plaintiffs and their attorneys face much the same economic incentives as other litigants, which should discourage weak claims. Indeed, as many studies show, people are not very ready to sue except in egregious situations. See, e.g., HANS, supra note 27, at 54-55; Nielsen \& Nelson, supra note 6, at 703-07; David M. Trubek et al., The Costs of Ordinary Litigation, 31 UCLA L. Rev. 72 (1983). Contingent-fee attorneys, as well as those looking to fee-shifting, are surely reluctant to bring questionable claims. See Kevin M. Clermont \& John D. Currivan, Improving on the Contingent Fee, 63 CoRnell L. Rev. 529, 536, 561-62, 571-73 (1978); Theodore Eisenberg \& Charlotte Lanvers, What Is the Settlement Rate and Why Should We Care? 26 (Sept. 17, 2008), available at http://ssin.com/abstract $==1276383$. The pool of employment discrimination claims might therefore be overpopulated by strong rather than weak claims.

Second, even if employment discrimination plaintiffs are flooding the district courts with weak cases, at least those stalwart few who make it through pretrial, through settlement negotiations, and then through to victory at trial should have relatively strong cases; these are cases that survived prefiling and pretrial screening, and so are nonfrivolous cases with a genuine factual issue. The settlement-litigation process should have weeded out the lopsided cases, leaving a pool of claims comprising mainly close cases. See Realities, supra note 2, at 137-42. Yet these tried cases exhibit a more extreme anti-plaintiff effect on appeal than do pretrial adjudications. This result is strongly inconsistent with any argument that weak cases produce these divergent reversal rates. 
Study of appeals is thus essential to understanding employment discrimination litigation. One can easily see that these plaintiffs do not do well in the district courts, although it is difficult to say exactly why. One can, with more effort, see that these plaintiffs do not do well in the courts of appeals, and here one can somewhat more solidly conclude that judicial attitudes are at play. The anti-plaintiff effect on appeal raises the specter that federal appellate courts have a double standard for employment discrimination cases, harshly scrutinizing employees' victories below while gazing benignly at employers' victories.

\section{District COURTS}

\section{A. Numbers of Cases}

As Display 5 reveals, the non-jobs part of the federal civil docket continued its rapid expansion in the early 1980 s-the so-called litigation explosion $^{35}$ - to reach an all-time peak of 263,804 cases terminated in 1985 , which was an increase of over eighty percent from six years earlier. Since 1985, however, that civil caseload has been flat, with only 262,239 cases terminated in 2005.

The employment discrimination caseload expanded later than the federal civil docket as a whole. ${ }^{36}$ The display shows that the number of cases grew modestly in the early 1980 s, and not at all in the late 1980s. In the

Third, our prior research across a whole range of case categories found that the anti-plaintiff effect on appeal prevails even between corporate parties. See Defendants' Advantage, supra note 11, at 136-38. Also, the anti-plaintiff effect exists separate from any "repeat-player haves"/"one-shot have nots" effect between opponents, as neither governmental litigants nor corporate litigants fared much differently from nongovernmental, noncorporate litigants in reversal rates. See id. at 138, 148-49, 157; Plaintiphobia, supra note 11, at 956-57, 970. That is, although there might be a "one-shot have nots" effect, there is a more important antiplaintiff effect. Where the "one-shot have nots" are always the plaintiffs, that effect conjoins with the anti-plaintiff effect. The result is a plaintiff/defendant differential of extraordinary magnitude in employment discrimination cases.

Fourth, even assuming that plaintiff/defendant differences explain the anti-plaintiff pattern seen on appeal in other case categories, employment discrimination cases stand out so sharply in this regard that one simply has to resort in part to an attitudinal explanation. No reasonable assumptions as to case strength, "one-shot have nots" effect, appeal rates, and judicial accuracy would produce the observed pattern. See Eisenberg, supra note 18, at 682-85 (finding a residual attitudinal effect in the data even for the example of employment discrimination cases with their extremely low win rate).

Therefore, rather than yielding to the intuitive attraction of the view that employment discrimination plaintiffs are overly litigious, we tentatively conclude that appellate judges are acting as if it is they who accept that view. Their resulting attitude then produces at least some of the observed anti-plaintiff effect.

${ }^{35}$ See Marc Galanter, Reading the Landscape of Disputes: What We Know and Don't Know (and Think We Know) About Our Allegedly Contentious and Litigious Society, 31 UCLA L. Rev. 4 (1983).

${ }^{36}$ The 1970s saw a dramatic percentage increase in employment discrimination cases because the base was so low, but the absolute increase was rather modest in those years. Our data show only 423 cases in 1971 . This number increased to 5,289 cases by 1979 , more than a twelve-fold increase, but an absolute increase of fewer than 5,000 cases. By contrast, the rest 


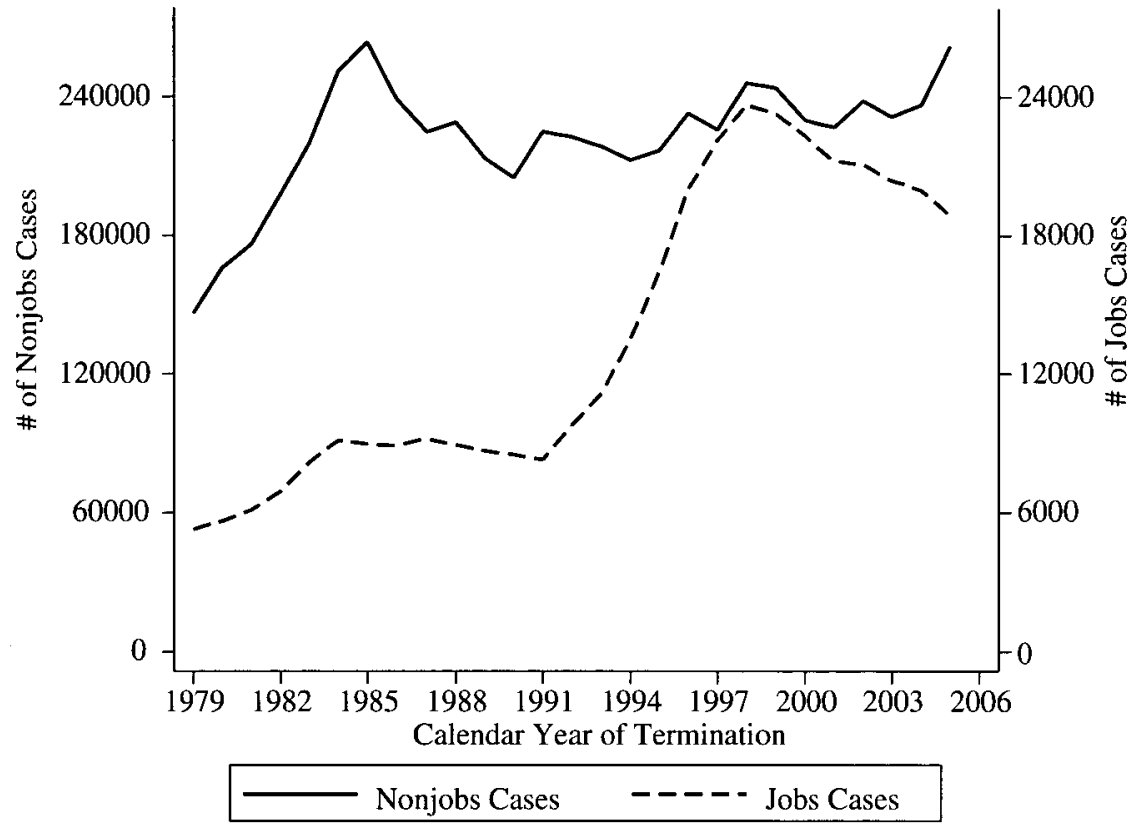

Display 5: Numbers of Cases for Employment Discrimination and Other Civil Cases, 1979-2005, U.S. District Courts. This graph of AO data shows the differently timed rises in employment discrimination and other cases, looking at those terminated since 1979. The other cases peaked in 1985 at 263,804 , and they were at 262,239 in 2005 . Employment discrimination cases peaked in 1998 at 23,722 , but they dropped to 18,859 by 2005 .

1990s, however, employment discrimination cases exploded from 8,303 cases terminated in 1991 to 23,722 cases terminated in 1998 , a $286 \%$ increase. This explosion of employment discrimination cases presumably resulted from several factors, most of which are beyond explanation by Administrative Office data. For example, the Civil Rights Act of 1991 made Title VII law more favorable to plaintiffs, increasing the propensity to sue; its changes included a right to jury trial and the availability of compensatory and punitive damages. ${ }^{37}$

Around the same time, new statutes created federal causes of action for new classes of employment discrimination plaintiffs. These included the Americans with Disabilities Act of $1990^{38}$ and the Family and Medical Leave Act of $1993 . .^{39}$ One should not overemphasize these new statutes, however. As Display 6 shows, only one in ten employment discrimination cases arises

of the civil docket had 90,820 terminations in 1971 and 146,160 terminations in 1979 , "only" a sixty percent increase, but an absolute increase of over 55,000 cases.

${ }^{37}$ Pub. L. No. 102-166, 105 Stat. 1071; see Nielsen \& Nelson, supra note 6, at 673-80, $687,692-700$ (contrasting statutory extensions with contemporaneous judicial retrenchment, but noting that the data nevertheless show the 1990s' explosion).

${ }^{38}$ See Ruth Colker, The Disability Pendulum: The First Decade of the Americans wirh Disabilities Act (2005).

${ }^{39}$ See David L. Hudson Jr., Changing Act, A.B.A. J., Sept. 2003, at 15 (saying that FMLA is gaining on $\mathrm{ADA}$ as an employee weapon). 


\begin{tabular}{|l|c|c|}
\hline Type & Number & Win Rate \\
\hline Title VII & 64,122 & 10.88 \\
\hline ADA & 8240 & 9.12 \\
\hline$\S 1983$ & 8342 & 11.24 \\
\hline ADEA & 7105 & 11.67 \\
\hline$\S 1981$ & 4457 & 10.96 \\
\hline FMLA & 1503 & 19.55 \\
\hline Total & 93,769 & 10.90 \\
\hline
\end{tabular}

Display 6: Numbers and Win Rates, Employment Discrimination Cases by Type, Fiscal 1998-2006, U.S. District Courts. This table of AO data shows the predominance of Title VII cases in code \#442 cases, as well as the similarity of outcomes in the different types of discrimination cases. We discuss win rates infra Part II.C. Only since fiscal year 1998 did the Administrative Office enter the title and section of the U.S. Code under which each case is brought, so our breakdown by type of discrimination can only begin then. Moreover, because the data go only through fiscal year 2006, the data from the last three months of calendar year 2006 are not included. Finally, the entries for title and section are poor, so we have discarded an almost equal number of missing or nonsensical entries.

under the ADA or the FMLA. Title VII cases constitute the bulk of jobs cases, nearly seventy percent. While the 1990 s did see a spike in, say, disability claims, the caseload increases were across-the-board among the types of employment discrimination..$^{40}$

Today, employment discrimination cases constitute a big fraction of the federal civil docket. By 2001, employment discrimination cases constituted nearly ten percent of federal civil terminations. But this category has seen a startling drop as a percentage of terminations every year since then, so that in 2006 it accounted for fewer than six percent of federal civil terminations. While the overall caseload is at least holding its own currently, the employment discrimination category has dropped in absolute number of terminations every year after 1998 , when the total was 23,722 , with only 18,859 cases terminated in 2005. The numbers for the jobs category are still dropping, ever more sharply, to 16,992 in fiscal year 2006 and 15,007 in fiscal year 2007, the latter being a drop of thirty-seven percent from the peak of 23,721 terminations in fiscal year 1999.41 There have not been similar declines in federal terminations over the same period for the groups of ordinary contract and tort cases, other nonprisoner civil rights cases, or other federal

${ }^{40}$ See Laura Beth Nielsen, Robert L. Nelson \& Ryon Lancaster, Uncertain Justice: Litigating Claims of Employment Discrimination in the Contemporary United States 14 (Amer. Bar Assoc. , Research Paper No. 08-04, Apr. 16, 2008), available at http://ssrn.com/abstract $=1093313$ (distinguishing race, sex, age, and disability). We would do better to divide up the case category on bases other than the statute involved, such as the type of discrimination, but our data do not permit that step. See Wendy Parker, Lessons in Losing: Race Discrimination in Employment, 81 Notre DAME L. Rev. 889, 895, 928 (2006).

${ }^{41}$ The computerized data took us only through the first nine months of 2006 . To pick up the subsequent year, we needed to refer to the AO's published tables for fiscal years. See Annual Report of the Director of the Administrative Office of the U.S. Courts tbl. C-4, available at http://www.uscourts.gov/judbususc/judbus.html. 
labor law cases. ${ }^{42}$ Moreover, all four of the sizable statutory types within the jobs category are trending downward..$^{43}$

This recent and sharp decline has received little notice and hence no real explanation. ${ }^{44}$ The only commentary noting the decline has suggested that it is not owing to a drop in the amounts of actual or perceived discrimination, but rather results from changing reactions to discrimination by victims and their lawyers: "The very significant downturn in filings since 1998 may well reflect the largely negative experiences of many plaintiffs and their lawyers." 45 That is, the plaintiff-side's learning curve dictated a decline in filings, as realization of the poor prospects in federal court dawned at the end of the 1990s' euphoria.

This discouragement hypothesis is a bit tautological, in that it explains a drop in lawsuits by proposing a declining propensity to sue. ${ }^{46}$ But the notion that discouragement is in reaction to results does receive support from data reflecting the drop in the number of cases circuit-by-circuit. Since the peak

${ }^{42}$ One does see a similarly sharp decline in prisoner civil rights cases, but a statutory change caused that drop, and prisoner litigation overall including habeas did not decline. See Margo Schlanger, Inmate Litigation, 116 HARv. L. Rev. 1555, 1558 n.4, 1634-42 (2003). A very recent government report indicates that the small category of housing discrimination cases shows a decline similar to the jobs decline, and demonstrates that filings in all categories of civil rights cases were declining over fiscal years 2005 and 2006. See Tracey Kyckelhahn \& Thomas H. Cohen, Civil Rights Complaints in U.S. District Courts, 1990-2006, BJS SPECIAL REP., Aug. 2008, at 3-4.

43 The decline exists for ADA cases even if the new codes $\# 445$ and $\# 446$ are included. See supra note 4.

${ }^{44}$ Instead, there have been reports of a recent spike in employment class actions, as well as reports of increases in other kinds of employment litigation. E.g., Julie Kay, Employers Start to Push Waivers, NaT'L L.J., June 9, 2008, at 8 ("overtime lawsuits have become the most common form of employment lawsuit"); Sheri Qualters, Firms Beef Up Employment Practices, NAT'L L.J., Mar. 17, 2008, at 10 ("Employment cases are increasingly likely to be labor-intensive class actions, instead of individual employees bringing grievances to court. .. ."); Fourth Annual Workplace Class Action Litigation Report from Seyfarth Shaw Notes Significant Growth in High Stakes Litigation at State Court Levels: Volume of Wage and Hour Litigation Continues to Increase Exponentially; Employment Discrimination Class Actions Theories and Remedies Continue to Evolve and Expand; and the Size of ERISA Class Action Settlements Outpace all Other Types of Class Action Resolutions, http://www.seyfarth. com/dir_docs/news_item/2a69ffe5-df15-475f-a78a-da0661200731_documentupload.pdf (Jan. 14,2008 ). Although class actions constitute only about a third of one percent of the number of cases in code \#442, see Nielsen \& Nelson, supra note 6, at 692, an increase in class actions could account for part of the drop in individual actions, unless the class actions mainly mobilized new sorts of plaintiffs. Additionally, the AO does not categorize wage-and-hour or equalpay suits as discrimination suits under code $\# 442$, but rather under code $\# 710$ for the "Fair Labor Standards Act."

${ }^{45}$ Nielsen et al., supra note 40 , at 33; see id. at 13-14 (reporting a drop in federal employment discrimination filings from a peak of 23,796 in fiscal year 1997 to 14,353 in fiscal year 2006). While the numbers of jobs case terminations were dropping sharply, the numbers of Equal Employment Opportunity Commission (EEOC) charges were holding steady, and the charges' mix of discrimination types was not substantially changing. See U.S. EEOC, Charge Statistics FY 1997 Through FY 2007, http://www.eeoc.gov/stats/charges.html (last visited Sept. 26, 2008); $c f$. Nielsen \& Nelson, supra note 6, at 687-91 (treating data through 2002). Those facts suggest there has been no drop in the amounts of actual or perceived discrimination.

${ }^{46}$ Cf. Changing Nature, supra note 3 , at 1003 (discussing a similar tautology). 
of 1998, after which the absolute drop in employment discrimination cases started, the steepest decline in case terminations comes in the Eleventh Circuit, with the Fifth, Fourth, Eighth, and Sixth Circuits following. Those circuits correspond well with those a plaintiffs' lawyer previously described as circuits perceived by the bar to be the most hostile to employment discrimination plaintiffs. ${ }^{47}$

Of course there are other possible explanations for the decline in jobs cases, even though it seems too sudden and big to rest on fundamental societal or workplace changes. Perhaps alternative dispute resolution, popular in the employment setting, ${ }^{48}$ has suddenly increased in popularity to the point of flipping the trend in case filings. But such a massive change would not have gone unnoted elsewhere. Alternatively, perhaps the plaintiffs are shifting to the greener pastures of state courts and managing to avoid removal. Unfortunately, state court data equivalent to the federal court data do not exist. ${ }^{49}$ In any event, both of these explanations are consistent with the idea that employment discrimination plaintiffs or, more realistically, their lawyers are becoming discouraged with their chances in federal court.

Professors Donohue and Siegelman have demonstrated that, previously, employment discrimination federal court filings decreased or increased in response to the ups and downs of the business cycle..$^{50}$ More precisely, filings, with a six-month lag, varied directly with the national unemployment rate. This relation was certainly plausible. ${ }^{51}$ The authors theorized that bad

${ }^{47}$ Interview with Cyrus Mehri, Partner of Washington, D.C.'s Mehri \& Skalet, PLLC, in Ithaca, N.Y. (Feb. 11, 2008) (notes on file with authors) (naming Fourth, Fifth, Sixth, and Eleventh Circuits). Another measure of circuit hostility might be the difference between the defendants' reversal rate and the plaintiffs' reversal rate on appeals from losses at trial in each circuit, but for any selection effect at play. All the circuits showed the anti-plaintiff effect, ranging from the D.C. Circuit at a 41.46 point differential on relatively few cases down through the Fifth, Sixth, Seventh, and Eighth Circuits to the national mean of 32.38 points down through the Tenth, Fourth, Second, Ninth, Eleventh, and First Circuits to the Third Circuit at 21.00 points.

${ }^{48}$ See Theodore Eisenberg \& Geoffrey P. Miller, The Flight from Arbitration: An Empirical Study of Ex Ante Arbitration Clauses in the Contracts of Publicly Held Companies, 56 DePaul L. Rev. 335, 351 (2007).

${ }^{49}$ The scant state data that do exist suggest that the state courts are not seeing a recent drop in employment discrimination cases. See E-mail from Nicole Waters, Senior Court Research Associate, Nat'l Center for State Courts, to Kevin M. Clermont (July 7, 2008) (on file with authors). Further circumstantial evidence lies in the interesting fact that for jobs the decline in original-case terminations is much greater than the decline in removed-case terminations. From 1998 to 2005 , the drop was $22.47 \%$ for original cases and only $6.96 \%$ for removed cases. This difference gives some support to our view that plaintiffs prefer a state forum to federal court.

${ }^{50}$ See John J. Donohue III \& Peter Siegelman, Law and Macroeconomics: Employment Discrimination Litigation over the Business Cycle, 66 S. CAL. L. Rev. 709 (1993); Peter Siegelman \& John J. Donohue III, The Selection of Employment Discrimination Disputes for Litigation: Using Business Cycle Effects to Test the Priest-Klein Hypothesis, 24 J. LeGaL STud. 427 (1995).

${ }^{51}$ Cf. Kathryn Harrison, Diagnosis: Female, N.Y. Times, Apr. 27, 2008, Book Review, at 13 (discussing George Taylor's observation that "hemlines rose and fell with the stock market, proposing a causal connection [women are bolder in times of prosperity] between two presumably separate spheres of human enterprise"). 
times' longer periods of unemployment magnified the back-pay that would be awarded, and so induced more court cases. However, their articles used filing data from fiscal years 1969-1988, and their business-cycle theory in particular aimed at explaining more the minor short-term ups and downs in the filings than the great long-term upward trend in filings over those years. ${ }^{52}$ Thus, their theory might not explain the sharp decline in cases during the new century. Display 7 explores their theory. It uses termination data rather than filing data, which would cause changes in the unemployment rate to precede any related changes in cases by about eighteen months..$^{53}$ It shows that the caseload does not vary directly with the unemployment rate. Indeed, no relation at all is apparent. Business cycles therefore do not explain the upward trend in cases during the 1990s or the subsequent decline..$^{54}$

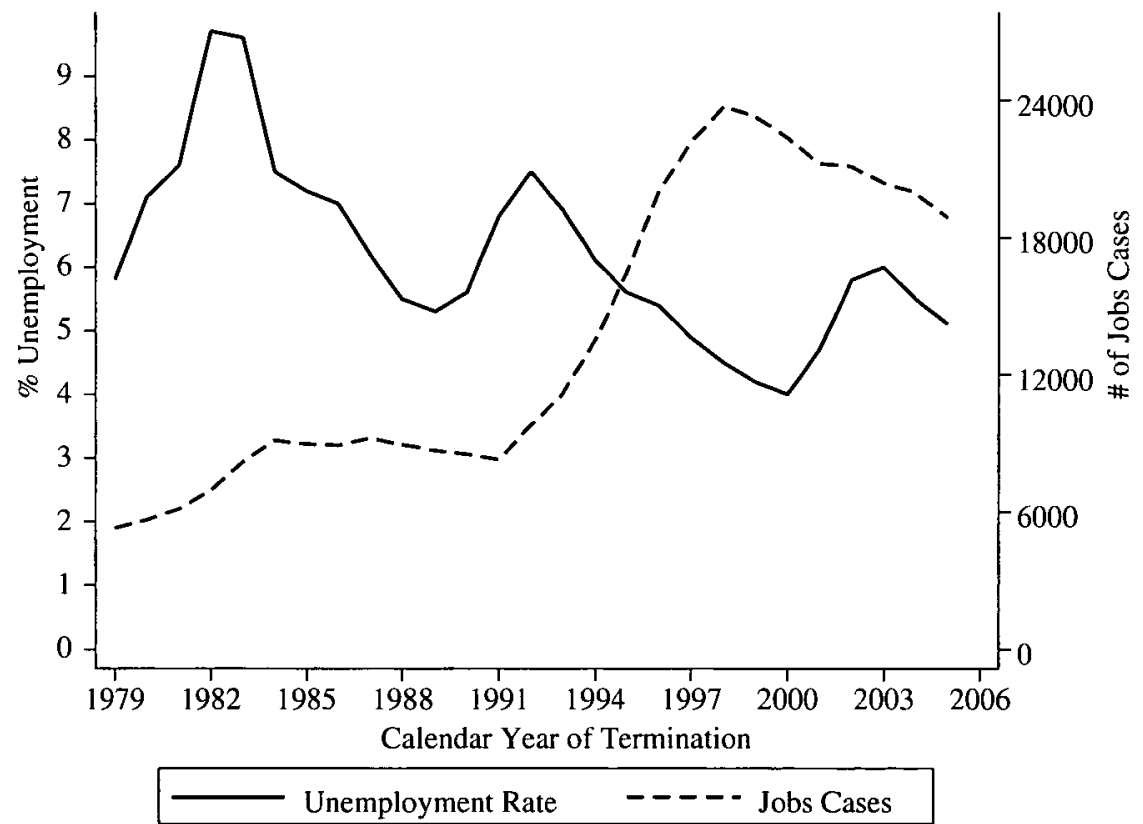

Display 7: Numbers of Cases for Employment Discrimination, 1979-2005, U.S. District Courts, Compared to Unemployment Rate. This graph of AO data, plotted against the annual unemployment rate for the nation as calculated by the Bureau of Labor Statistics, U.S. Dep't of Labor, http:// www.bls.gov/cps/prev_yrs.htm, shows the lack of relation between the two.

52 See Changing Nature, supra note 3, at $985-1000$.

${ }^{53}$ See Nielsen \& Nelson, supra note 6, at 692-93 (pegging the median duration of jobs cases at around a year).

${ }^{54}$ In fact, Donohue and Siegelman predicted that the Civil Rights Act of 1991 would produce a strong upward trend in cases during the 1990s, and also that its expansion of remedies beyond back-pay would dampen the cyclical pattern they had observed. See Donohue \& Siegelman, supra note 50 , at 765 . Later they noted that these predictions had come true, so that "there is essentially no business cycle relationship apparent for the period after 1991." Evolution, supra note 3, at 275. 
Instead, for our purposes the most useful point emerging from the Donohue and Siegelman articles is that employment discrimination plaintiffs and their lawyers do respond to economic incentives. Therefore, if litigating becomes more apparently a fruitless endeavor, one would expect to see a decline in employment discrimination cases. Discouragement thus could explain the recent downturn in the number of cases. It is not necessarily that plaintiffs' chances have taken a dive in recent years (their win rate is not diving, although admittedly their win rate would look worse if they continued to bring the weak cases that they are now choosing not to bring ${ }^{55}$ ). Rather, there could be a growing awareness, especially with the prolonged lack of success on appeal, that employment discrimination plaintiffs have too tough a row to hoe.

\section{B. Disposition Procedures}

The data in this subsection show that employment discrimination plaintiffs manage fewer resolutions early in litigation compared to other plaintiffs, and so they have to proceed toward trial more often. Defendants' resistance reflects awareness of their good chances in court.

Pretrial. Using percentages rather than absolute numbers, Display 8 shows that, like other cases, most employment discrimination cases settle, with more and more doing so with the passing years. ${ }^{56}$ Almost seventy percent of employment discrimination and other cases are terminated by settlement, used here in the sense of an uncontested termination. A much smaller number of dispositions fall into a welter of other-disposition codes, predominantly remand or transfer to another court. As a matter of probability, most of these other dispositions will result, after additional proceedings, in an eventual settlement rather than a final adjudication, so the bigger this

${ }^{55}$ See Siegelman \& Donohue, supra note 50, at 451 (showing that win rate increases as filing rate decreases).

${ }^{56}$ For these purposes, tried cases are those with a method-of-disposition value of 7-9. Cases adjudicated without trial are those with a method-of-disposition value of $6,15,17,19$, or 20 . Settled cases are those with a method-of-disposition value of $2,4,5,12-14$, or 18 . Code 3 switched in usage around 1991 from voluntary dismissal to dismissal for lack of jurisdiction, so we grouped its earlier usage with settlement but its usage in 1991 and later with nontrial adjudication. "Other" dispositions are all remaining method-of-disposition values, predominantly remand or transfer to another court. This division is more suggestive than authoritative, because these AO data are unavoidably shaky. See Kevin M. Clermont, Litigation Realities Redux, 84 Notre Dame L. Rev. (forthcoming May 2009) (manuscript at 29-31), available at http://ssrn.com/abstract $=1112274$. Moreover, the settlement rate depends critically on one's definition of settlement, and here we are defining it by distinction from a contested judgment. Thus, the high settlement rate does not imply lots of success for plaintiffs. See Eisenberg \& Lanvers, supra note 34, at 15, 21-28 (showing that if one defines settlement more in terms of a compromise by the parties that represents some success by the plaintiff, the settlement rate for employment discrimination is considerably lower for jobs cases than for non-jobs cases). In fact, a lowered success rate for plaintiffs through settlement would be consistent with our other observations for jobs cases compared with non-jobs cases: fewer early terminations, lower plaintiff win rate on pretrial motions, more trials, lower plaintiff win rate on trials, the exaggerated anti-plaintiff effect on appeal, and of course the diving number of filings for jobs cases. 


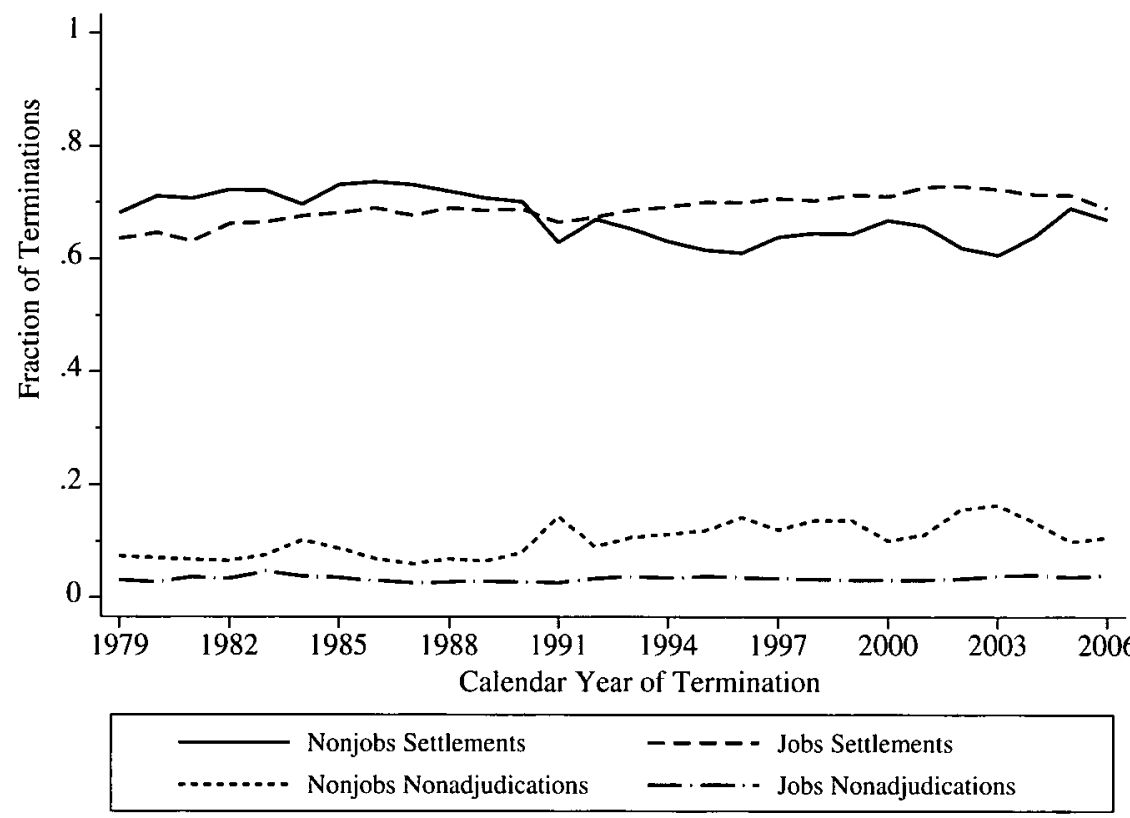

Display 8: Nonadjudication Rates in Employment Discrimination and Other Cases, 1979-2006, U.S. District Courts. This graph of AO data shows the rates of settlement and other nonadjudication in employment discrimination and other cases. As the top two lines show, the fraction of cases that reach a disposition through settlement has comparatively increased for employment discrimination cases. As the bottom two lines show, an offetting trend is that the fraction of cases resolved by "other" forms of dispositions, labeled here as "nonadjudications," has become comparatively lower for employment discrimination cases.

nonadjudication grouping is, the more settlement there is. Far fewer than half as many dispositions fall into this other-disposition grouping for employment discrimination cases as for other cases. Therefore, employment discrimination cases probably do not settle more frequently than other cases.

Moreover, a quick aside to procedural progress, as opposed to disposition method, reveals that far fewer employment discrimination cases end early in the litigation process (thirty-seven percent, compared to other cases at fifty-nine percent)..$^{57}$ Compared to other plaintiffs, employment discrimination plaintiffs remain less likely to obtain an early end and more likely to have to slog onward. As Display 9 shows, nontrial adjudications, predominantly by pretrial motion but also including judgments confirming decisions by arbitrators and magistrates, have over the years stayed comparable for employment discrimination and other cases, at about twenty percent of cases. It seems to be gently increasing with time. By contrast, the trial rate

${ }^{57}$ For this calculation, we used the codes for procedural progress. The early phase included codes $1-3$ and 11-12. The trial phase included codes 6-9. The middle phase included the other codes. For jobs cases, $36.66 \%, 55.46 \%$, and $7.88 \%$ ended at the early, middle, and trial stages, respectively, while the numbers for non-jobs cases were $58.57 \%, 38.08 \%$, and $3.35 \%$. 


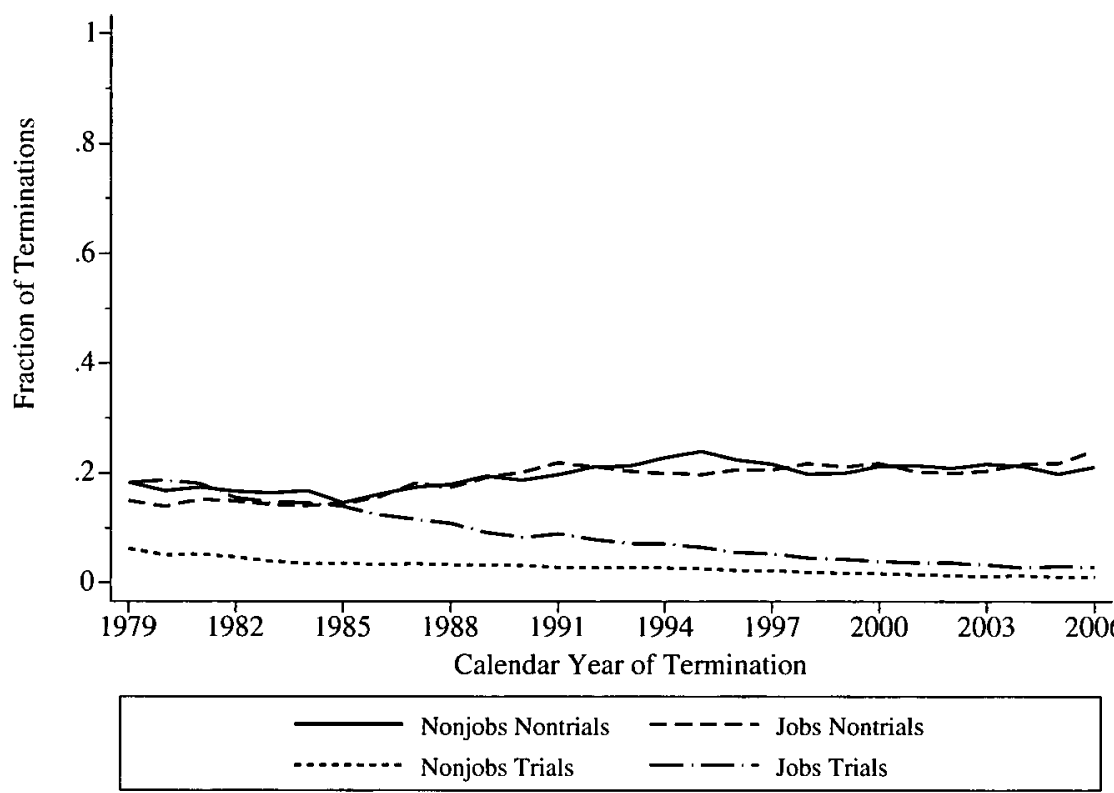

Display 9: Adjudication Rates in Employment Discrimination and Other Cases, 1979-2006, U.S. District Courts. This graph of $\mathrm{AO}$ data shows the rates of trial and other adjudication in employment discrimination and other cases. As the top two lines show, the fraction of cases that reach a disposition through nontrial adjudication, labeled here as "nontrials," are comparable for employment discrimination and other cases. As the bottom two lines show, the fraction of cases resolved by trial is comparatively higher for employment discrimination cases, as the fraction of cases resolved by trial has fallen from $18.2 \%$ in 1979 to $2.8 \%$ in 2006 for employment discrimination cases, but from $6.2 \%$ in 1979 to the even lower level of $1.0 \%$ in 2006 for other cases.

for employment discrimination cases exceeds that for other cases. But all trials are in steady decline.

In sum, only a small percentage of any category of cases make it through the procedural system to a contested judgment, nontrial or trial. Displays 8 and 9 tell an overall story of the continuing dominance of settlement, against a backdrop of a diminishing role for trial.

Trial. The dramatic result of these trends is the increasing prominence of employment discrimination trials as a fraction of all trials. On the one hand, as non-trial dispositions in non-jobs cases have increased in the last two decades, the civil trial has all but withered away. ${ }^{58}$ Although trials in non-jobs cases have long been relatively rare, they now are exceedingly rare. Display 10 shows a sixty-nine percent decline in the number of non-jobs trials. Many have noted this trend while disagreeing about the cause, but in some sense the trend must result from the increasing caseload. ${ }^{59}$ On the other hand, although trials have become rare even in jobs cases, ${ }^{60}$ the "van-

${ }^{58}$ See Realities, supra note 2, at 136-37, 142-44.

${ }^{59}$ See Clermont, supra note 56, at 31-35.

${ }^{60}$ A study of docket sheets from the Southern District of New York over four years showed an employment discrimination trial rate of $3.8 \%$, with a plaintiff win rate at trial of 33.6\%. Michael Delikat \& Morris M. Kleiner, An Empirical Study of Dispute Resolution 


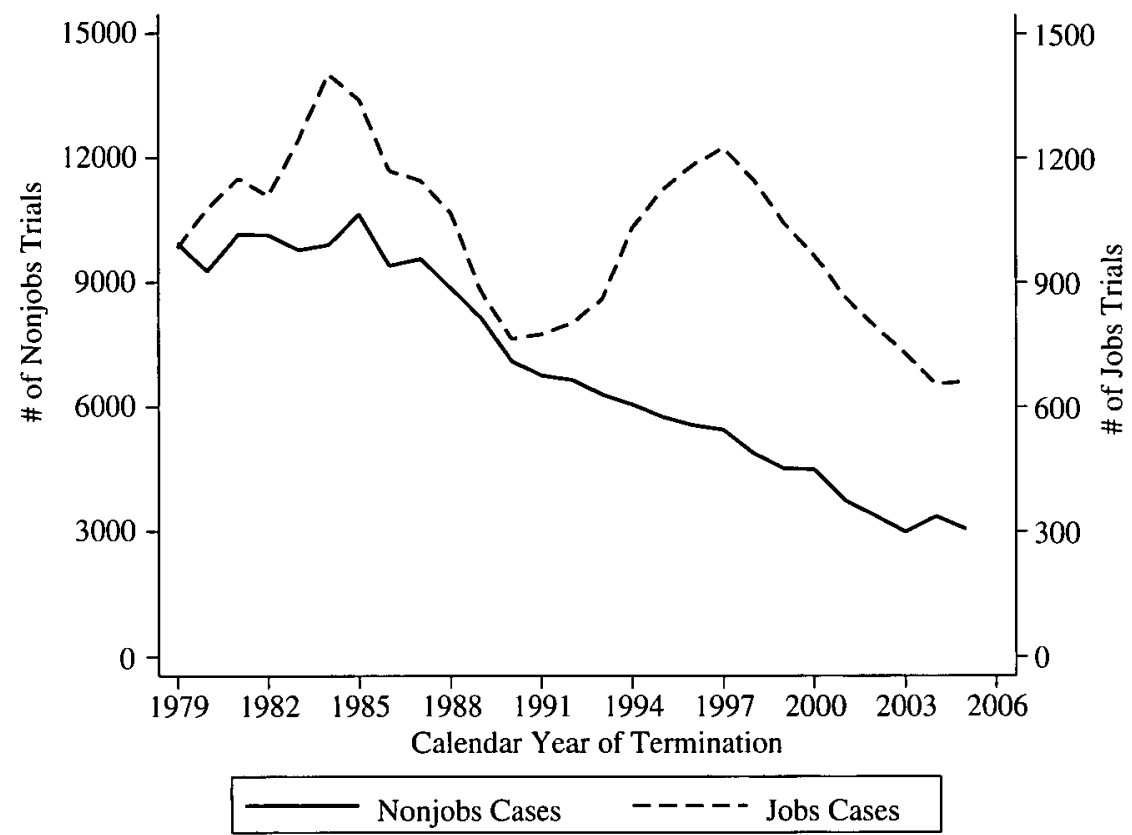

Display 10: Numbers of Trials in Employment Discrimination and Other Civil Cases, 1979-2005, U.S. District Courts. This graph of AO data shows the decreasing numbers of cases terminated at trial. There were 9956 non-jobs trials in 1979 and only 3059 in 2005 . Meanwhile, there were 983 jobs trials in 1979, a peak of 1402 in 1984, and a low of 661 in 2005.

ishing trial" is not so characteristic of jobs cases. The number of jobs trials has decreased by only thirty-three percent. Whereas the ratio of non-jobs trials to jobs trials was 10:1 in 1979, it was only 4.6:1 in 2005 .

Again, compared to other plaintiffs, employment discrimination plaintiffs remain more likely to have to undergo trial. The heightened anti-plaintiff effect on appeal could have a role to play here too. Defendants may be marginally less willing to settle, early or at all, when they know that they can get a favorable second chance in the courts of appeal should they lose at trial.

Lumping judge and jury trials together masks some remarkable divergences in trends. As Display 11 shows, the number of judge trials has plummeted in the last two decades, both for employment discrimination cases and for other cases. Although the downward trend is dramatic for both types of cases in percentage terms judge trials have fallen more in employment discrimination cases. In the early 1980s, judges tried as many as a thousand employment discrimination cases per year. In 2005, there were fewer than a hundred.

Jury trials tell a different story, as related by Display 12 . In employment discrimination cases, the annual number of jury trials has increased. 


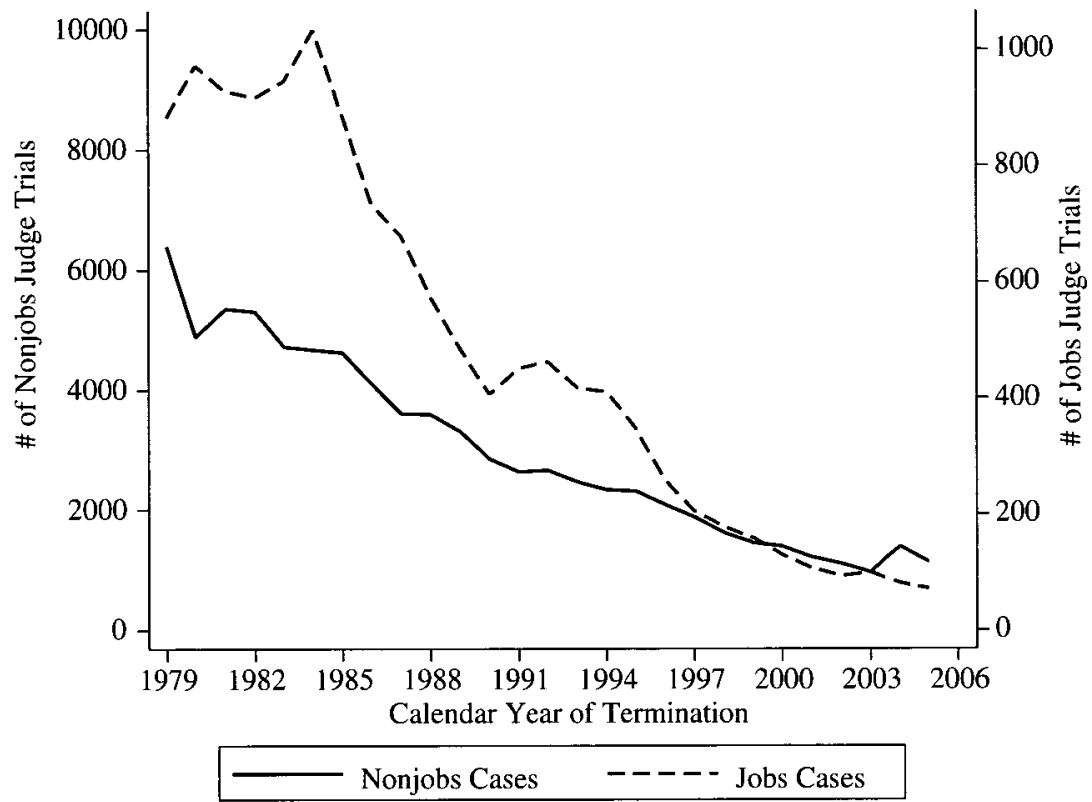

Display 11: Numbers of Judge Trials in Employment Discrimination and Other Civil Cases, 1979-2005, U.S. District Courts. This graph of AO data shows the plummeting numbers of judge trials. There were 884 employment discrimination judge trials in 1979, a peak of 1034 in 1984, and 71 in 2005. For other cases, there were 6403 judge trials in 1979 and only 1130 in 2005.

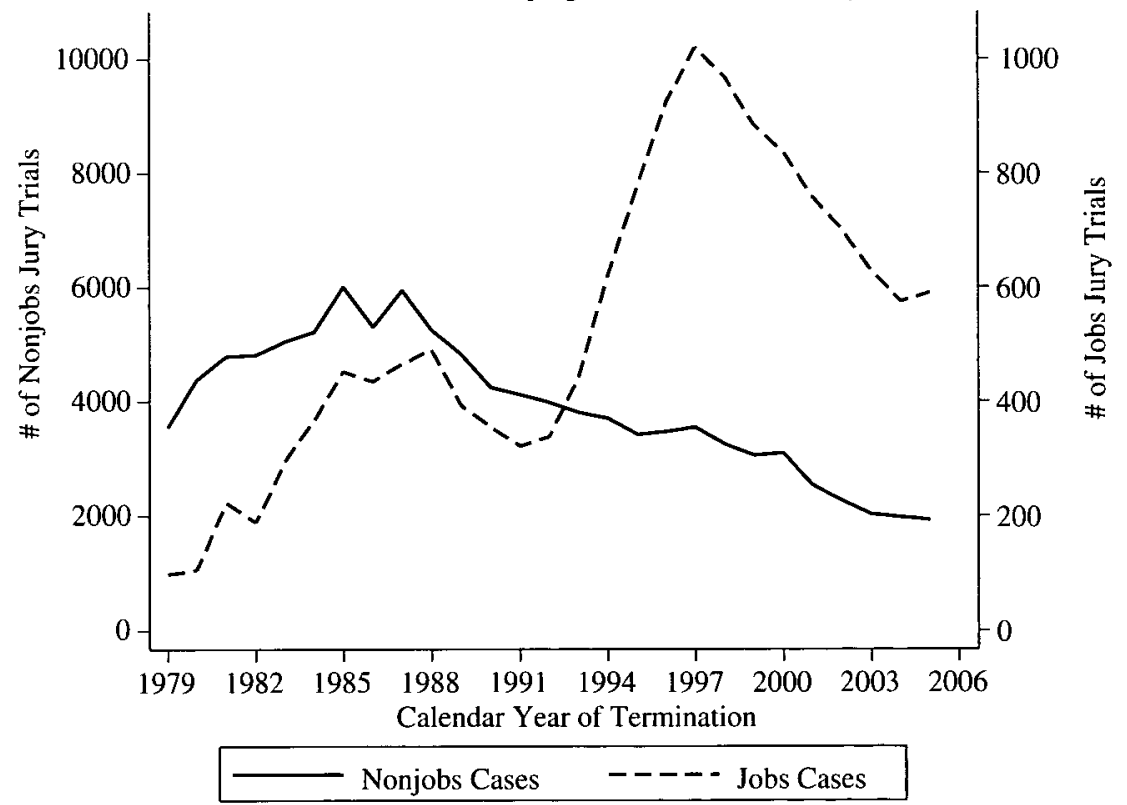

Display 12: Numbers of Jury Trials in Employment Discrimination and Other Civil Cases, 1979-2005, U.S. District Courts. This graph of AO data shows the different time trends for jury trials in employment discrimination and other cases. The number of employment discrimination jury trials rose from 99 in 1979 to a peak of 1020 in 1997, and then fell to 590 in 2005 . For other cases, there were 3553 jury trials in 1979, a peak of 6017 in 1985, and 1929 in 2005. 
The increase was dramatic after 1991, when jury trials were first allowed for Title VII cases, but the trend had been upward for most of the 1980s as well. Recently, the number of jury trials in employment discrimination cases has dropped sharply. By contrast, the number of jury trials in other cases has fallen steadily, by sixty-eight percent, from its peak in the mid-1980s.

The upshot emerges in Display 13. The ratio of jury trials to all trials has increased in all types of cases, although it now appears to be leveling off. In non-jobs cases, over the twenty-eight-year period the ratio went from under two out of five to over three out of five. The ratio in jobs cases much more dramatically increased: in 1979, only about one in ten trials was a jury trial; by 2006, jury trials were about nine in ten. Compared to other plaintiffs, jobs plaintiffs prefer jury trial to judge trial.

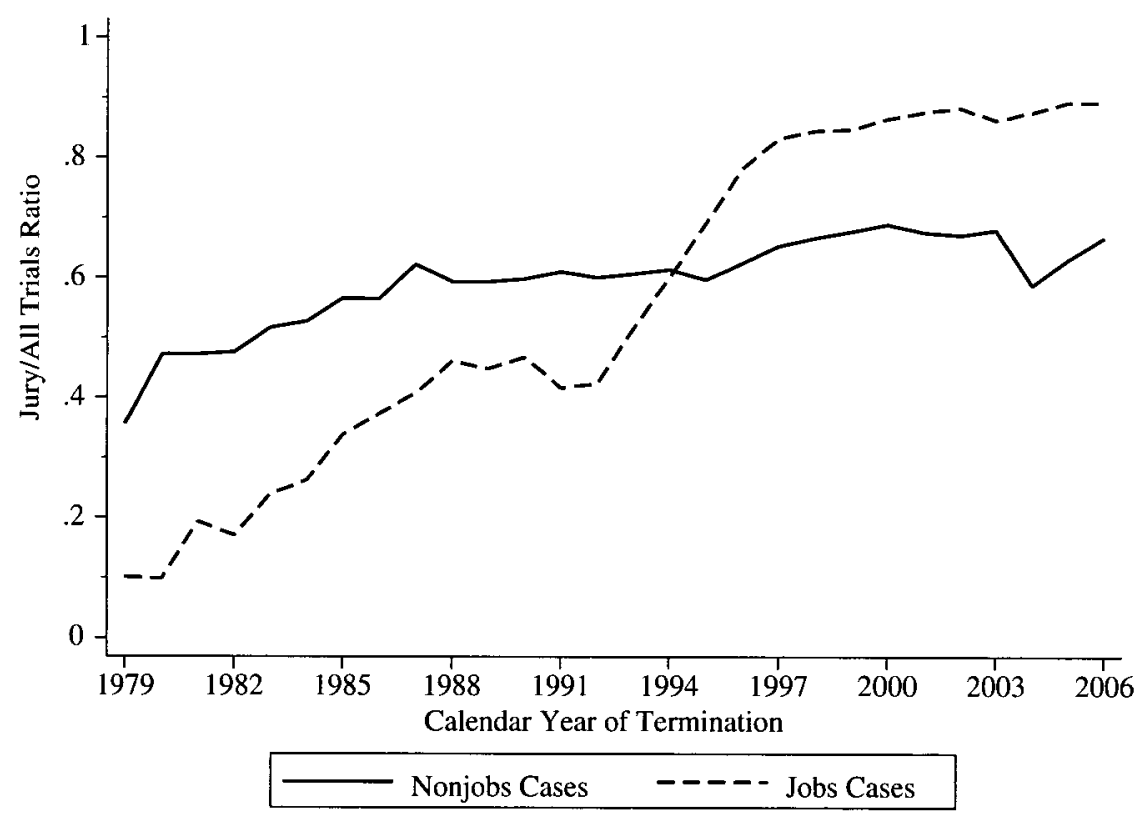

Display 13: Ratio of Jury Trials to All Trials in Employment Discrimination and Other Civil Cases, 1979-2006, U.S. District Courts. This graph of AO data shows the increasing predominance of the jury mode of trial. In $1979,10 \%$ of employment discrimination trials were to juries; in $2006,89 \%$ were jury trials. In $1979,36 \%$ of trials in other cases were to juries; in $2006,67 \%$ were jury trials.

The cause of these rising ratios for all cases remains obscure. ${ }^{61} \mathrm{~A}$ lot more analysis remains necessary for a confident understanding of the causes

${ }^{61}$ The explanation for the rising ratios is especially mysterious because both trial queues are regulated by the same person, the trial judge. The explanation would have to be a broad one, not linked to a particular category of case. Perhaps the explanation lies in judicial distaste for a time-consuming task like bench trial; or, as the disincentives to any trial have increased, those litigants who prefer jury trial have proved to be the more determined group.

But a major contributing factor appears to be that the federal courts do nothing-they neither make litigants wait longer for jury trial nor impose any special user fee-to discourage 
of the vanishing trial, or even of the real size of the decline given a changing legal environment. ${ }^{62}$ There also remains the contentious issue of the normative implications of the vanishing bench trial and civil trial. ${ }^{63}$ But at least for employment discrimination cases, part of the causal explanation lies in comparative win rates before juries and judges.

\section{Win Rates}

The most significant observation about the district courts' adjudication of employment discrimination cases is the long-run lack of success for these plaintiffs relative to other plaintiffs. Over the period of 1979-2006 in federal court, the plaintiff win rate for jobs cases (15\%) was much lower than that for non-jobs cases $(51 \%)$. Perhaps this outcome results merely from defendants' arguably having differentially higher stakes in the outcome. ${ }^{64}$ But perhaps it results from hurdles being placed before employment discrimination plaintiffs. ${ }^{65}$

Pretrial. The gap in win rates between employment discrimination plaintiffs and other plaintiffs appears, for example, in pretrial adjudication. ${ }^{66}$

that more costly mode of trial, for which either party can opt. See Clermont, supra note 56, at 24-26. State courts, which generally discourage jury trials by imposing delays, have exhibited the opposite pattern: jury trials have fallen more precipitously than a broadly defined set of judge trials. See Brian J. Ostrom et al., Examining Trial Trends in State Courts: 1976-2002, 1 J. Empirical Legal Stud. 755, 770, 777 app. D (2004).

${ }^{62}$ See generally Stephen B. Burbank, Keeping Our Ambition Under Control: The Limits of Data and Inference in Searching for the Causes and Consequences of Vanishing Trials in Federal Court, 1 J. Empirical Legal Stud. 571 (2004); Gillian K. Hadfield, Where Have All the Trials Gone? Settlements, Nontrial Adjudications, and Statistical Artifacts in the Changing Disposition of Federal Civil Cases, 1 J. Empirical Legal Stud. 705 (2004); Margo Schlanger, What We Know and What We Should Know About American Trial Trends, $2006 \mathrm{~J}$. DISP. RESOL. 35.

${ }^{63}$ Compare, e.g., Paul Butler, The Case for Trials: Considering the Intangibles, $1 \mathrm{~J}$. EMPIRICAL Legal Stud. 627 (2004) (arguing that the shift toward compromise and away from trials is troubling), with, e.g., Stephen C. Yeazell, Getting What We Asked For, Getting What We Paid For, and Not Liking What We Got: The Vanishing Civil Trial, 1 J. EMPIRICAL Legal STUD. 943 (2004) (arguing that declining trial rates do not reflect a crisis in the judicial system).

${ }^{64}$ See Siegelman \& Donohue, supra note 50, at 461. Although the defendants do have reputational losses to consider as well as the effect of losing on future cases, employees certainly have considerable emotional costs at stake, and their higher marginal utility of money might also create a differentially higher stake.

${ }_{65}$ See Nielsen \& Nelson, supra note 6, at 701-03; Michael Selmi, Why Are Employment Discrimination Cases So Hard to Win?, 61 LA. L. Rev. 555, 557-58 (2001). As an example, a jury verdict reporter study of California state and federal employment law cases during 1998-1999 found that women and minorities fared particularly badly as plaintiffs in discrimination and wrongful discharge jury trials, as compared to other kinds of plaintiffs and to other kinds of employment cases. David Benjamin Oppenheimer, Verdicts Matter: An Empirical Study of California Employment Discrimination and Wrongful Discharge Jury Verdicts Reveals Low Success Rates for Women and Minorities, 37 U.C. DAvis L. Rev. 511 (2003). Another study of both published opinions and case files from 2002 and 2003 found that employment discrimination plaintiffs in race and national origin cases also fared particularly badly. Parker, supra note 40 .

${ }^{66}$ Here, again, we define pretrial adjudication as those cases whose method of disposition was coded as 6 , which means disposition by pretrial motion. 
Display 14 shows the fairly persistent gap over time, even while the win rate for pretrial adjudication was trending down in all cases. Over the period of 1979-2006 in federal court, employment discrimination plaintiffs have won $3.59 \%$ of pretrial adjudications, while other plaintiffs have won $21.05 \%$ of pretrial adjudications.

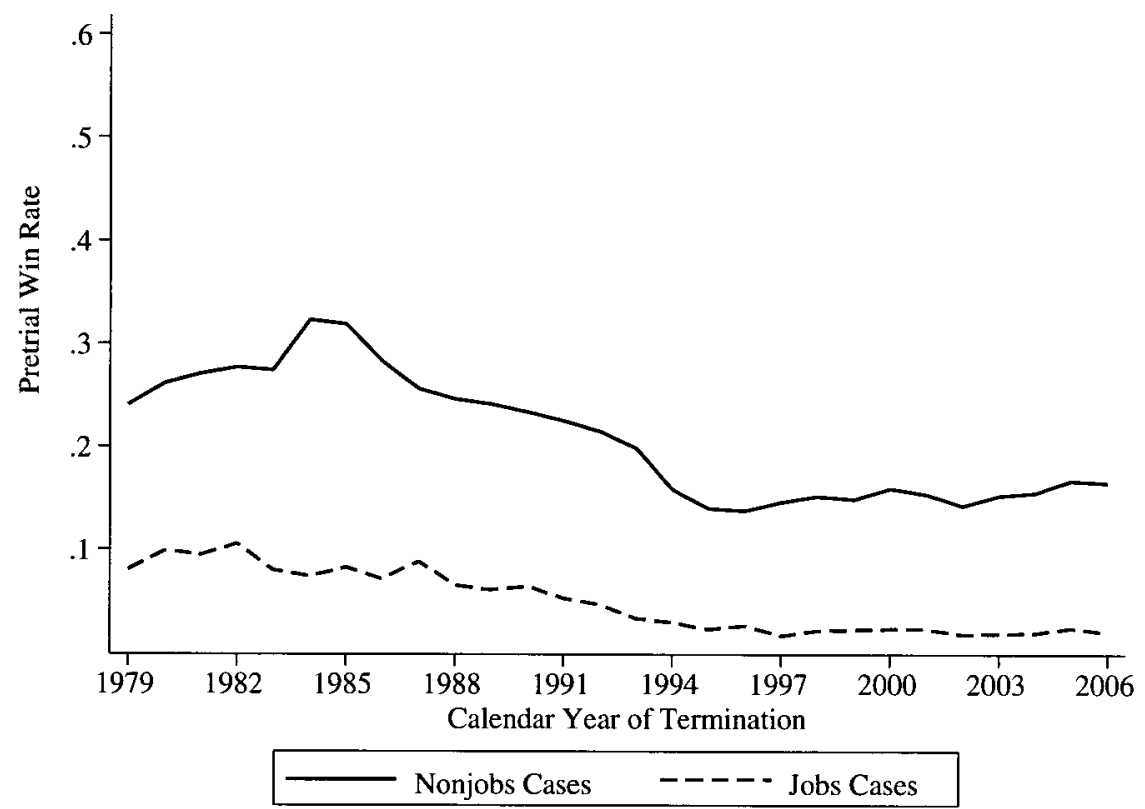

Display 14: Plaintiff Win Rates for Pretrial Adjudication in Employment Discrimination and Other Civil Cases, 1979-2006, U.S. District Courts. This graph of AO data shows that employment discrimination plaintiffs fare worse on pretrial adjudication than other plaintiffs.

Of course, defendants make many more motions for summary judgment, and succeed on them more often, than do plaintiffs. ${ }^{67}$ So one would expect a low plaintiff win rate in pretrial adjudication, as this number reflects the percentage of cases terminated by motion that go in the plaintiff's favor rather than in the defendant's favor. Still, the difference in win rates between jobs cases and non-jobs cases shows that pretrial adjudication particularly disfavors employment discrimination plaintiffs. ${ }^{68}$

${ }^{67}$ See Joe S. Cecil, Rebecca N. Eyre, Dean Miletich \& David Rindskopf, A QuarterCentury of Summary Judgment Practice in Six Federal District Courts, 4 J. EMPIRICAL Legal STUD. 861, 886-89 (2007).

${ }^{68}$ One fine study of employment discrimination cases looked at a sample of cases from two districts during a period around 2000 and found that the court decided summary judgment motions by defendants in $22.8 \%$ of the cases, with the defendants experiencing a $63.6 \%$ success rate on those motions (with a much higher rate against pro se plaintiffs). Vivian Berger et al., Summary Judgment Benchmarks for Settling Employment Discrimination Lawsuits, 23 Hofstra Lab. \& EMP. L.J. 45, 53, 55 tbl.1, 57 tbl.3 (2005) (examining the Eastern and Southern Districts of New York). Thus, summary judgment is a common means of disposing of this category of cases. See Theodore Eisenberg \& Charlotte Lanvers, Summary Judgment Rates Over Time, Across Case Categories, and Across Districts: An Empirical Study of Three Large Federal Districts 2-3 (Cornell Law Sch., Research Paper No. 08-022, May 22, 2008), available 
Trial. For cases going to trial, employment discrimination plaintiffs (28.47\%) again win less often than other plaintiffs (44.94\%), although the gap was closing over time. As Display 15 shows, in the 1980s, employment discrimination plaintiffs won trials at only half the rate of other plaintiffs. In the 1990s the gap in win rates narrowed substantially. Although the same smaller gap has persisted in the most recent years, the much lower filing rate might be hiding an effectively lower win rate. ${ }^{69}$

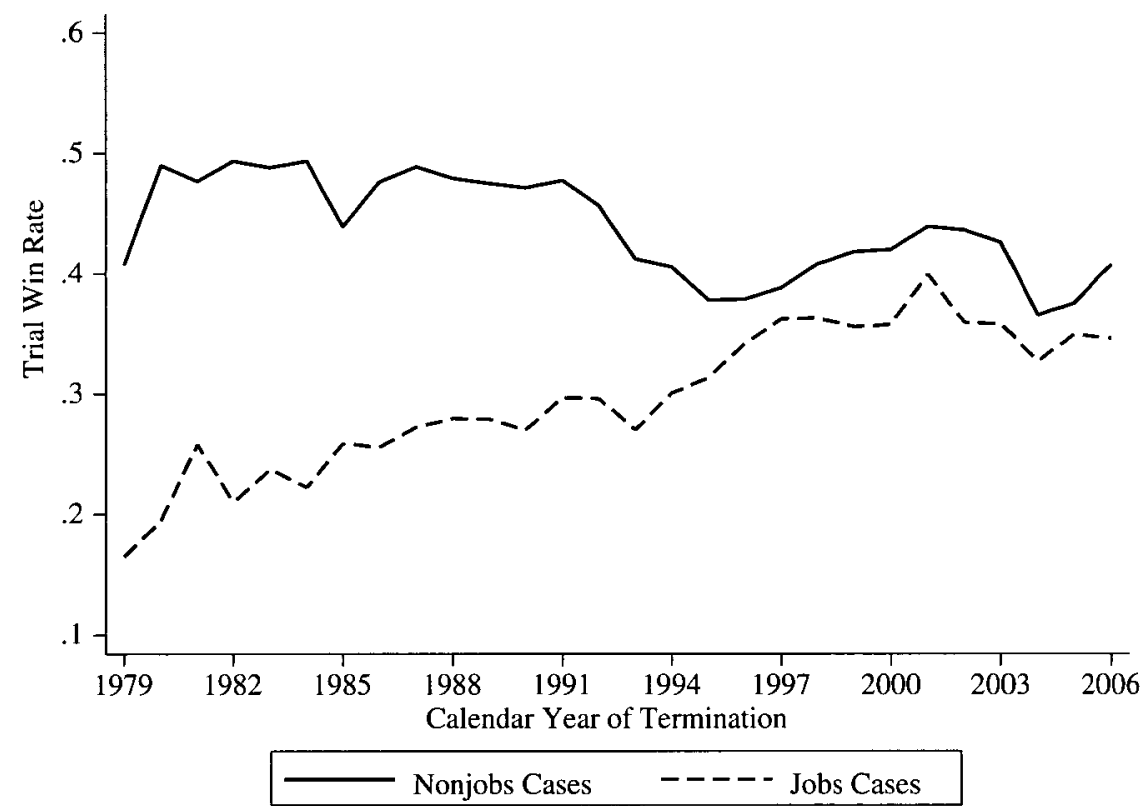

Display 15: Plaintiff Win Rates at Trial in Employment Discrimination and Other Civil Cases, 1979-2006, U.S. District Courts. This graph of AO data shows the closing gap in plaintiff win rates at trial. Win rates in employment discrimination cases rose from $16.5 \%$ in 1979 to $34.6 \%$ in 2006. Win rates in other cases ranged from a peak of $49.4 \%$ in 1984 to a low of $36.5 \%$ in 2004 , and then to $40.7 \%$ in 2006 .

One reason for the relatively rising trial win rate in employment discrimination cases seen in Display 15 during the 1990s could be the shift to jury trials seen in Displays 12 and 13. That is, the shift toward jury trial through 1997 might have increased the overall trial win rate in employment discrimination cases through 1997 . That possibility requires investigating the comparative win rates before juries and judges.

at http://ssrn.com/abstract $=1138373$ (examining cases from the Eastern District of Pennsylvania, Northern District of Georgia, and Central District of California); Nielsen et al., supra note 40, at 16-18. Moreover, a sampling of judicial opinions available online regarding defendants' summary judgment motions in Title VII employment discrimination cases showed a statistically significant effect of the political party of the President who had appointed the trial judge on the outcomes in those cases. John Friedl \& Andre Honoree, Is Justice Blind? Examining the Relationship Between Presidential Appointments of Judges and Outcomes in Employment Discrimination Cases, 38 CuMB. L. REv. 89 (2007).

${ }^{69}$ See supra note 55 and accompanying text. 


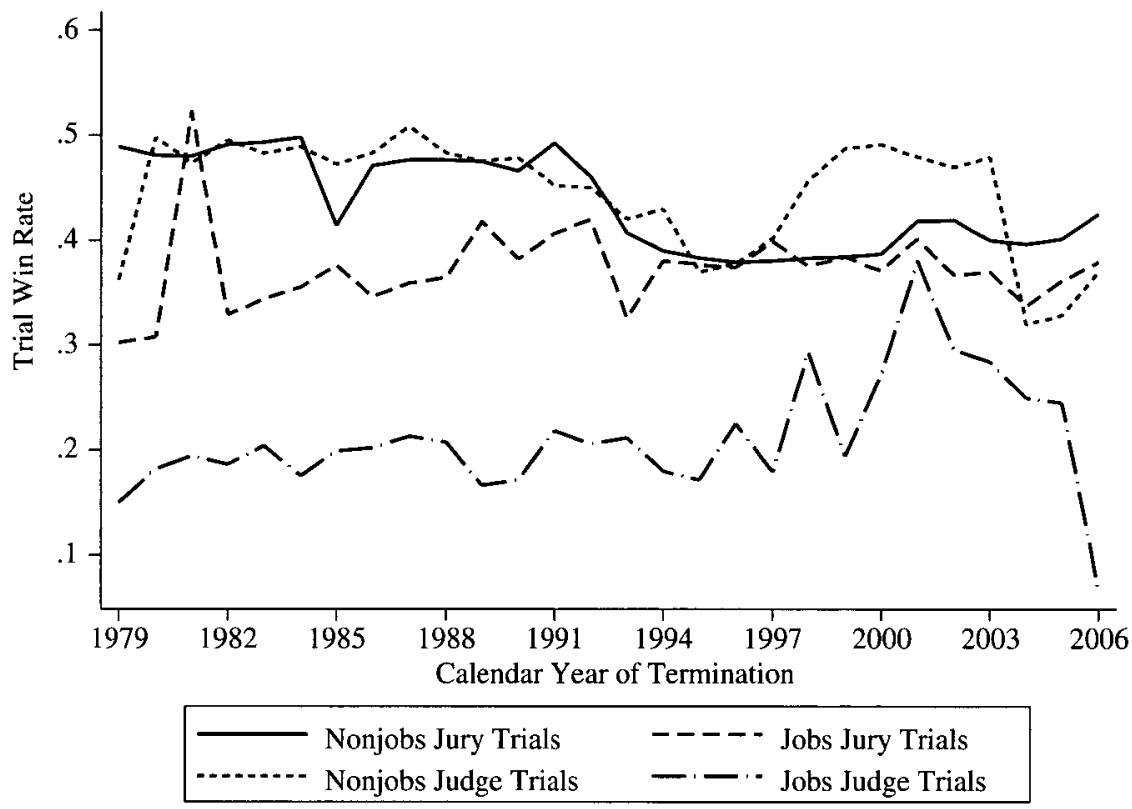

Display 16: Plaintiff Win Rates at Jury and Judge Trials in Employment Discrimination and Other Civil Cases, 1979-2006, U.S. District Courts. The top two lines of this graph of AO data show the nearly indistinguishable plaintiff win rates in jury and judge trials in non-jobs cases. The bottom two lines show the large gap in jury and judge win rates in jobs trials. The dive in 2006 for jobs judge trials is owing to the volatility of small numbers: plaintiffs won only two of thirty trials in the covered nine months.

Display 16 breaks down the trial win rates to show the jury and judge win rates over time. The win rates in jury trials of employment discrimination and other cases are not far apart, being $37.63 \%$ and $44.41 \%$ respectively. This difference generates the persisting small gap in win rates seen in Display 15 , because jury trials are now so much more frequent than judge trials.

By contrast, the win rate in judge trials has been much lower in employment discrimination cases than in other cases. Employment discrimination plaintiffs, unlike most other plaintiffs, have always done substantially worse in judge trials than in jury trials. In numbers, employment discrimination plaintiffs have won only $19.62 \%$ of judge trials. While employment discrimination plaintiffs have thus won fewer than one in five of their judge trials, other plaintiffs have won $45.53 \%$ of their judge trials.

These patterns of jury and judge win rates over time are as easy to misinterpret as they are hard to explain. We believe that in most situations juries and judges act similarly, although they are seeing distinct flows of cases. $^{70}$ Certain groups of plaintiffs might do far worse before judges or

${ }^{70}$ See Trial by Jury, supra note 13, at 1170-74. We concluded at the end of that lengthy article, based on a wealth of data covering all sorts of cases, that (1) the most plausible explanation of those data lies in small differences between judges' and juries' treatment of cases and, 
juries, but the reason most often lies in prevailing misperceptions about judges or juries that prompt lawyers to put before each fact finder different kinds of cases.

In employment discrimination litigation, however, it may be that trial judges are more demanding of plaintiffs than juries are, or at least are exhibiting a well-founded fear of any judgments for plaintiffs being more likely reversed. The parties do not fully perceive this: if a jury trial were available, one side or the other would request it to escape any perceived judicial leaning; if a jury trial were not available, over the long run the parties should settle their cases in light of a perceived leaning so as to generate the normal background win rate. Thus, the parties do not perceive the full extent of the trial judges' departure from neutrality. When the judges instead turn out to lean against plaintiffs even more than expected, plaintiffs see a lowered win rate. The parties' misperceptions therefore produce a persistently lower win rate in judge trials than in jury trials. The trial judges' leaning against plaintiffs might also help to explain plaintiffs' consistent disadvantage in pretrial adjudication, as seen in Display 14.

\section{ConClusion}

Today employment discrimination plaintiffs still must swim against a strong tide -in the federal district court and on appeal. Findings for these cases compared to other civil cases include fewer early terminations and more trials; lower success rates for plaintiffs by settlement and lower plaintiff win rates at pretrial adjudication and trial, especially judge trial; and more appeals. Maybe the situation has not gone from bad to worse in the last five years. But those plaintiffs may have gone from merely faring badly to feeling bad about their chances for success, which would affect their litigation behavior.

For the prime example of continuing adversity, defendants in the federal courts of appeals have managed over the years to reverse forty-one percent of their trial losses in employment discrimination cases, while plaintiffs manage only a nine percent reversal rate. The most startling change in the

much more substantially, in the parties' varying the case selection that reaches judge and jury; (2) litigants' stereotypical views about juries may lead them to act unwisely in choosing between judge trials and jury trials; and (3) atypical differences in win rates before judges and juries for certain case categories may stem from the especially strong misperceptions litigants hold about jury behavior in these cases.

A key example in that article was product liability and medical malpractice litigation, in which the win rates substantially differ from other categories' win rates and in a surprising way: plaintiffs in these two areas prevail after trial at a much higher rate before judges (48\%) than they do before juries (28\%). We theorized that lawyers settle cases in a way that leaves for trial by jury or judge a residue of what they consider close cases. Then, because lawyers view the jury as relatively favorable to plaintiffs in these categories, juries see on average weaker cases than do judges. The perceptions of jury sympathy turn out to be misperceptions, as jury and judge perform similarly. Thus, the jury produces fewer winners than expected, while the judge produces more winners. 
last few years' data is the substantial drop of almost forty percent in the number of employment discrimination cases in the federal district courts.

Findings like these prompt speculation. Perhaps the plaintiffs' lawyers are now recognizing their low chances for success in federal court, and thereby becoming less inclined to venture into a court system that they view as impeding the realization of rights congressionally bestowed on workers. Nonetheless, the breathtaking pace of change since last we wrote on employment discrimination litigation is the principal discovery that this article reports, and it counsels against yet embracing any explanation with confidence. 